University of Louisville

ThinkIR: The University of Louisville's Institutional Repository

9-1976

\title{
One Blake : the principles and method of visionary awakening in The Marriage of Heaven and Hell, Milton, and Jerusalem.
}

Richard Lee Record

University of Louisville

Follow this and additional works at: https://ir.library.louisville.edu/etd

\section{Recommended Citation}

Record, Richard Lee, "One Blake : the principles and method of visionary awakening in The Marriage of Heaven and Hell, Milton, and Jerusalem." (1976). Electronic Theses and Dissertations. Paper 1191.

https://doi.org/10.18297/etd/1191

This Master's Thesis is brought to you for free and open access by ThinkIR: The University of Louisville's Institutional Repository. It has been accepted for inclusion in Electronic Theses and Dissertations by an authorized administrator of ThinkIR: The University of Louisville's Institutional Repository. This title appears here courtesy of the author, who has retained all other copyrights. For more information, please contact thinkir@louisville.edu. 
ONE BLAKE

The Principles and Method of Visionary Awakening in The Marriage of Heaven and Hell, Milton, ard Jerusalem

\author{
By \\ Richard Lee Record \\ B.A., University of Lơuisville, 1974
}
A Thesis
Submitted to the Faculty of the
Graduate School of the University of Louisville in Partial Fulleillment of the Recuirements
for the Degree of

Master of' Arts

Department of English

university of Louisville

Louistille, tentucky

Sectember 1976 


\section{ONE BLAKE}

The Principles and Method of Visionary Awakening in The Marriage of Heaven and Hell, Milton, and Jerusalem

\section{By}

Richard Lee Record

B.A., University of Louisville, 1974

A Thesis Approved on

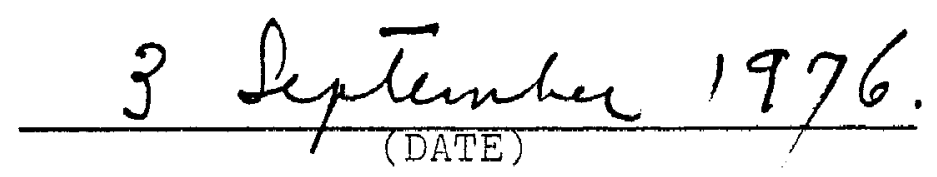

by the Following Reading Committee:

Thesis Director

Dean or Cheirman 


\section{ABSTRACT}

Essential to an understanding of William Blake is the knowledge of his intense identification with the messianic "perfect prophet," described by the Old Testament prophets, St. John, and Milton, and of the thematic unity which this identification produces in his work. The principles which lead to the attainment of this prophetic role--visionary awakening--and the moment of vision itself are the raw materials for his canon and provide the framework for his three key engraved works. The principles of visionary awakening and the epiphanic moment are outlined in The Marriage of Heaven and Hell, elaborated in Milton, and extended to all humanity in Jerusalem. Far from representing a divided man outside tradition, one kind of thinker in his youth and another in his later years, these works represent a single individual, identifying himself with "All the Lords people" as "One Man." 


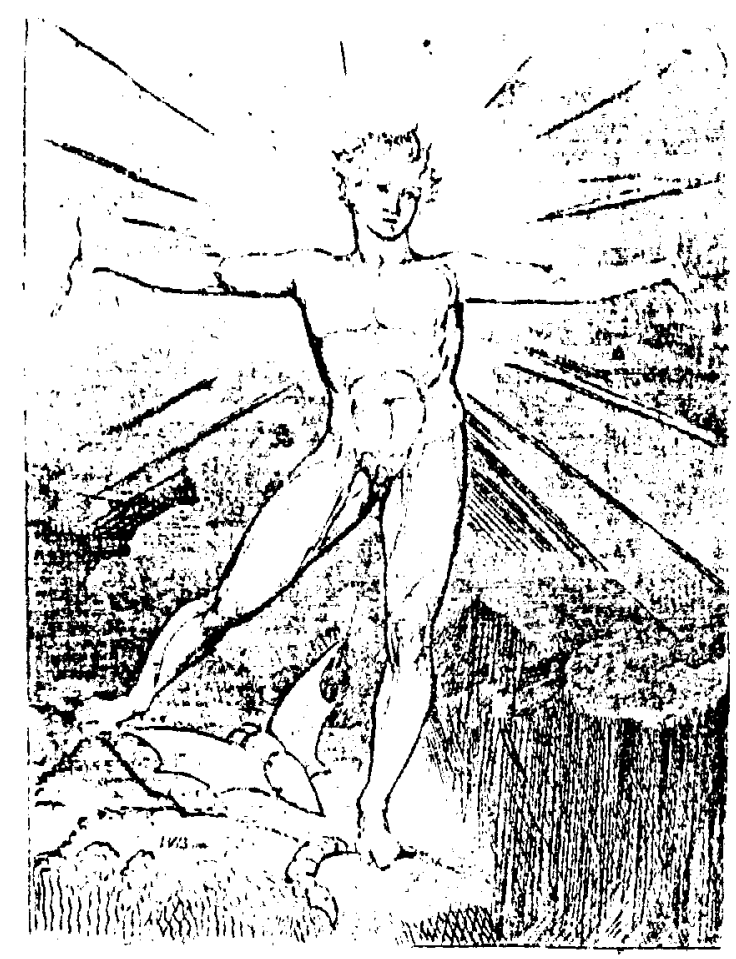

FIGURE 1: National Gallery of Ait, Rosenwald Collection.

\section{GLAD DAY}

And Blake awoke. Expanding from the Vale of Felpham, his Humanity became A Globe of Seli-annihilating flame, A Bubble searing through the Mundane Shell. Consumed in liquid Wrath, the torpid Sea With dolorific shrieks regenerates The raving Spectre's vegetated States of aggregated mediocrity.

The stoking of his bawling Furnace done, His burnished Anvil glinting in its beams, The Forge of his Imagination seems A distant Orb, a dark but shining Sun, Whose visionary radiance redeems The Mental Wariare Milton had begur. 


\section{ACKNOWLEDGMENTS}

I wish to acknowledge my very great debt to Dr. Mary Ellen Rickey, who taught me to appreciate Milton, and to Dr.J. P. Starling, whose support throughout this project has been true Spiritual Friendship. 
TABLE OF CONTENTS

\section{Page}

ABSTRACT . . . . . . . . . . . . . . . . . . iii EPIGRAPH . . . . . . . . . . . . . . . . . IV ACKNOWLEDGMENTS . . . . . . . . . . . . . . V LIST OF FIGURES . . . . . . . . . . . . . . . . . . . Vii INTRODUCTION . . . . . . . . . . . . . . . . I CHAPTER

I. THE PERFECT PROPHET . . . . . . . . . . . . 3

II. THE ANNUNCIATION . . . . . . . . . . . . . 12

III. THE EPIPHANIC MOMENT . . . . . . . . . . . 19 IV. TO PROPHESY THE WAYS OF GOD TO MAN . . . . . . 47

V. TILL VE HAVE BUILT JERUSALEM . . . . . . . . 85 SEIECTED BIBLIOGRAPHY . . . . . . . . . . . . 103

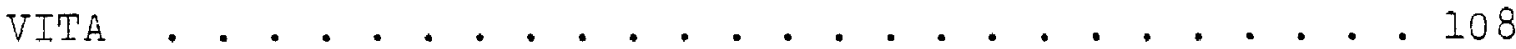




\section{LIST OF FIGURES}

\section{Page}

FIGURE I. Glad Day . . . . . . . . . . . . . iv

FIGURE II. The Frame of Jerusalem . . . . . . . 95

FIGURE III. Golgonooza . . . . . . . . . . . . 96 


\section{INTRODUCTION}

In The Marriage of Heaven and Hell, William Blake describes the world view of a paranoid schizophrenic, a topsy-turvy universe of endless torment, masocistic and egoistic guilt, and self-righteous pity, a universe which is an abstract product (and therefore dead) of the limited perceptions of fallen man. The reason of the Angel's party weeps and rails against the uncontrolled libido of the laughing Devil's party. Tortured, blazing from within with mindless desire and freezing without with analytical ratiocination, the fallen man lives in a Mundane Egg of psychotic isolation, wandering through nightmares of artificial reality in what seem to be ceaseless cycles of revolution and repression. Yet within the very source of his agony lies the foundation of his perceptual salvation, for a "marriage" of the contrary aspects of his being will enable his expanding consciousness to burst the Mundane Shell of restricted perception and hatch the reintegrated individual.

\section{The Marriage of Heaven and Hell outlines the} philosophical and artistic puinciples which will allow this expansion of consciousness (perhaps I should say awakening) and identifies the visionary agent whose personal moment of transfiguration in (and as) the poem Milton "enables Blake 
to experience so movingly intimations of that time when 'All Animals upon the Earth' will 'go forth to the Great Harvest \& Vintage of the Nations' ( 142 : 39; 43: 1)."1 This paper will deal with the principles and method of prophetic, visionary awakening as set forth in The Marriage of Heaven and Hell, the working out of those principles and methods in the Mental Warfare of the poet-prophet to purify and perfect his own vision in Milton, and the extension of that expanded, perfected vision to all humanity in a poetic realization of Apocalyptic awakening in Jerusalem. The major burden of the study will rest with the "moment of vision" itself, which is the poem Milton, but it will, of course, make some attempt, insofar as the limited scope of this thesis will allow, to discuss the context of apocalyptic prophesy, particularly in the works of Milton, Ezekiel, Isaiah, Job and Revelation.

IJoseph Anthony Wittreich, Jr., Angel of the Apocalypse: Blake's Idea of Milton (Madison: The University of Wisconsin Press, 1975), p. 238. All references to Blake's writings are to The Poetry and Prose of Wiliam Blake, ed. David V. Erdman, rev. ed. (Garden City, N. Y.: Doubleday \& Company, Inc., 1970) unless otherwise indicated. The following abbreviations are employed: MHH for The Marriage of Heaven and Hell, M for Milton, I for Jerusalem, VLJ for A Vision of the Last Juagment. 


\title{
THE PERFECT PROPHET
}

\begin{abstract}
Universal purposefulness. . . is a matter of perspective.
\end{abstract}

--Richard Record

A major difficulty with much of the criticism of the prophecies of Wiliiam Blake, particularly The Marriage of Heaven and Hell, is that the critics seem almost to forget that they are dealing with works of art, meticulously crafted by an author who was doubtless familiar with Milton's remark, "The Author is ever distinguisht from the person he introduces." ${ }^{\prime}$ Blake himself echoes this comment in one of his cryptic annotations:

Thus Fools quote Shakespeare; the above

is Theseus' opinion Not Shakespeare's.

You might as well quote Satan's

blasphemies from Milton \& give

them as Milton's Opinions.

${ }^{1} J o h n$ Milton, An Apology for Smeclymnuus, in Complete Prose Works of John Milton, I, ed. Don M. Wolfe et al. (New Haven: Yale University Press, and London: Oxford University Press, 1953), p. 880. All future quotations of Milton's Prose follow this edition, hereafter cited as Yale Milton, and are given parenthetically within the text. References to Milton's poetry are to The Complete Poetry of John Milton, ed. John T. Shawcross, rev. ed. (Garden City, N. Y.: Doubleday \& Company, Inc., 1971) and are likewise given parenthetically. The following abbreviations are employed: PI for Paradise Lost and PR for Faradise Regained.

$$
{ }^{2} \text { Joseph Anthony wittreich, Jr., ed. The }
$$

Romantics on Milton: Eomal Essays and Critical Asides 
Despite such forthright statements by Blake, even critics who recognize that "the vocabulary of the Marriage is altogether ironic, and requires close attention. . ." are capable of insisting "The Voice of the Devil' that follows is Blake's own. . . ." 3

Such reasoning leads to the erroneous conclusions that the critique of Milton is entirely serious and therefore is to be taken as a literal statement of Blake's views, that the Memorable Fancies are merely transcriptions of dreams or visions experienced by Blake, and that the work as a whole is based on a simple inversion of the traditional notions of good and evil. The work is variously described as a chaotic jumbling of unorganized ideas, a carefully devised satire, a radical attempt to create a totally new form, and even "a medley of genres" which "have in common a limitation of meaning imposed by their form - . [that] Blake was able to transcend. . in the myth of A Song of Liberty. "4 The Marriage of Heaven and Hell, however, is none of these things.

(Cleveland: The Press of Case Westem Reserve University, 1970), o. 341 .

3 Harold Blcom, Biake's Apocalypse: I Study in Poetic Argument (Garden City, M. Y.: Doubleday \& Company, Inc., 1963), ps. 77-78.

4 Mary $V$. Jackson, "Prolific and Devourer: From Nonmythic to Mytnic statement in The Marriage of Heaven ard Hell and A Song of Liberty," Journal of English and Germanic Philology, $70(1971)$, D. 207 . 
Rather, as Joseph Wittreich remarks, "it is a prophecy . . whose structure is modeled upon that of the Book of Revelation." 5 Blake employs a seven part structure ( 7 visions, each followed by a commentary), drawn from the Book of Revelation, to delineate four principles which are developed more fully in the mythological apocalypse of his epics. I have chosen to formulate those principles as follows :

1. Man's nature is fourfold, and the fully realized potential of that nature is the identity of the divine.

2. Each man's individuality, expressed in his desires and energies, is intrinsically valuable, and therefore no one man's vision is sufficient to be imposed externally upon others.

3. Perception through the five senses is essentially subjective and greatly limited when closed to the non-sensory dimension of the imagination.

4. One must be wiliing to know excess in order to approach a balance between his contrary aspects of "purposive activity and restorative passivity."6 Drawing its themes from biblical prophecy, Milton, and other apocalyptic sources, "The Marriage of Heaven and Hell is more exactly about the way in which apocalypse is

\section{Joseph Anthony wittreich, Jr., Angel of} Apocalypse: Blake's Idea of Milton (Madison: The University of Wisconsin Press, 1975), p. 192.

6 I am indebted to June $\mathrm{H}$. Singer, The Urholy Bible: A Psychological Interpretation of William Blake New Tork: G. F. Putnam's Sons for the C. G. Jung Fourdation for Analytical Psychology, 1970), Fo. 84-85, though I have condensed and somewhat altered her own formulation of what sine calls "the basic ordering themes" of the Provercs of Hell. 
realized--by annihilating erroneous doctrines as a prelude to the assimilation of new perspectives." 7 New perspectives, of course, is what every prophet, especially Blake, tries to provide, "the fundamental principle of human perception. . explicitly stated" in the remark, "All that we saw was owing to your metaphysics. . ." 8 The "metaphysics" of fallen reason so greatly limits the human perspective that all other aspects of man's being are either dismissed as non-existent or feared and repressed as evil. What the fallen reason fears (i.e., the greater part of Man's imaginative being) it imprisons in its fabrications of "heavenly" and "natural" law.

Blake's great psychological insight (later developed in scientific terms by Jung) is that the nature of the total human personality is fourfold, not singular or dualistic, and that the ideal human condition is one of balance among the tensions created by full acceptance of each of the opposing forces. Blake employs the biblical image of the wheel within wheels, but considering the equation of Tharmas (the Zoa of Unity or Proportion) with the sea in his fallen state, I believe an equally appropriate image for the integrated, unfallen man is the

7 Wittreich, Angel of Apocalypse, p. 199.

8 Morris Eaves, "A Reading of Blake's Marriage of Heaven and Hell, Plates 17-20: On and Under the Estate of the West," Blake Studies, 4 (Spring 1972), p. 81. 
bubble. Tharmas forms the unifying skin of "water" against which the Zoas of Head, Heart, and Loins exert perfectly balanced pressure. Should any one of the forces exert more or less tension than the others, the bubble collapses into a sterile blob, encrusted with generation's vegetable growth of Selfhood, though not entirely a solid mass because eruptions of doubt and revolt keep it ever unstable.

Anyone who would reestablish the bubble of his fourfold personality and reclaim the unfallen state must be willing to purge himself of his selfhood and become a prophet:

- . he should step into the fires of hell and undergo the personal sacrifice which this means. For who can expect to walk in fire and yet live, unless he is willing to take a new view of life, an eternal rather than a limited view? And is it not essential before anything novel can be created that the dross of what was before must be burned away so that the essential nature of the new may be perceived? This is the mood of Blake's entrance into Hell: a commitment to exposing himself to ideas in a totally different way. 9

Thus, Blake's formula for becoming a prophet is an artistic return from myopic paranoia to mental health, an apocalyptic self realization:

Man is caged by the perceptions of his senses, by his habits of reasoning and his acquisition of the methods of logic. Tradition bolts the door and neurosis intimidates and finally kills the desire to escape. But this bird, the bird of imagiration, . . the poetic spirit in man. . Is abie to cut the airy way, . . to enter the world of pure spirit. The 
senses are left behind, and the "world of delight" is ahead. This is Heaven and, paradoxically enough, Heaven only becomes available to the man who has dared to venture into Hel1.10

The clearest description of the structure of The Marriage of Heaven and Hell and its place in the prophetic tradition has been provided by Wittreich, who points out that although "the human situation may alter, the pattern of the prophet's response does not."Il Thus, the Marriage, like the Book of Revelation, is constructed in units of twenty-two "in accordance with the Hebrew alphabet" of twenty-two characters, contains seven visions and seven commentaries which are bounded by two free verse poems beginning the work "with a message of doom" and concluding it "with a message of hope and redemption," combines poetry and prose, is dramatic in structure, and moves from obscurity toward clarity in its statement. 12 Wittreich charts the seven part structure of the work in the following manner:

Prologue: Plates 1-2.

Vision Plate 3, paragraph 1.

10 Ibid., p. 78 .

11 Angel of Apocalypse, $P .190$.

12Ibid., pp. 190-195. Wittreich draws from and quotes Abraham Heschel, The Prophets: Part I, 2 vols. (New York: Harper and Row, 1971), p.xili, and Bishop Lowth, Isaiah: A New Translation; with a Preliminary $\frac{\text { Dissertation, and Notes Critical, Philological, and }}{\text { Explanatory, 2nd ed. (London: J. Nichols, 1779), p. 1i. }}$ 
I

Commentary Plate 3, paragraphs 2-4.

Vision Plate 4.

II

Commentary Plates 5-6, through "Note."

Vision Plates 6-10.

III

Commentary Plate ll.

Vision Plates 12-13.

IV

Commentary Plate 14 .

Vision Plate 15.

$\mathrm{V}$

Commentary Plates 16-17, through ". . . are our Energies."

Vision Plates 17-20.

$\mathrm{VI}$

Commentary Plates 21-22, through ". . . candle in sunshine."

Vision Plates 22-24, through ". . as Elijah."

VII

Commentary Plate 24 , "Note."

Epilogue: Plate 25.13

Looking more closely at this structural breakdown, one can see that The Marriage is further organized in units of twenty-two. "The Argument" is a poem in twenty-two lines. "A Song of Liberty" is composed of "20 verses, pius the colophon and the Choral speech." And the sevenfold prophecy framed by these two poems is laid out in twenty-two plates. 14

$$
\text { 13 Ioid., pp. 194-195. }
$$


The dramatic structure of The Marriage, set up in "The Argument," is built about a dialectic of two perspectives and the three classes of men who participate in the antagonism of those perspectives. These three classes, the Reprobate, the Redeemed, and the Elect, who figure so importantly in Milton, are represented in "The Argument" by Rintrah, the just man, and the sneaking serpent or viliain. However, in the prophecy they are given their fullest expression in the personae of the Devil (identified with Milton), the Narrator, and the Angel (identified with Swedenborg). Most commentators on The Marriage see the antagonism as dualistic rather than threefold, but the Narrator is no more a Devil than Palamabron is a Reprobate. He represents the focal point of the dialectic, the man whose sight has embraced the visionary perspective but is also capable of viewing the universe through the eyes of the Angelic materialist. Fe has been won over by the Devil, but the Angel continues to try to "save" him. The Narrator occupies a very important position in The Marriage because, as one of the Redeemed, he is capable of purging himself of error and, by allying with the Reprobate, assuming the mantle of the "perfect prophet":

- . his fiery Chariot drawn with two blazing Meteors figur'd like beasts. . . , resembling two of those four which Ezeciel and S. John saw, the one visag'd like a Lion to expresse power, high autority, and Indignation, the other of count'nance like a man to cast derision and scorne upon perverse and fraudulent 
seducers. . . Thus did the true Prophets of old combat with the false; thus Christ himselfe the fountaine of meeknesse found acrimony anough to be still galling and vexing. (Yale Milton I, 899-900)15

${ }^{15}$ Quoted by Wittreich, Angel of Apocalypse, p. 197 . 
CHAPTER II

THE ANNUNCIATION

With these matters of organization and thematic principles in mind, we are ready to turn to the work itself. The title page promises a marriage of Heavenly Reason and Hellish Energy and offers a pictorial representation of that marriage of contraries in a blend of important Blakean symbols. The eternal feminine rises from the fires of Hell to embrace the eternal masculine, reclining on the clouds of Heaven, while above them other couples frolic in the flames and still more act out the life of generation on the surface of the earth:

the trinity of Earth, Heaven and Hell suggests the dynamic quality associated with the number three. But the fourth is also present, and we see it as a disk of gold shining behind the heads of the two major figures. As a perfect circle with no beginning or end, as a sphere which suggests the whole earth or the sun, it is both center and circumference. It is the place where the opposites meet, and also it is the Iuminous occurrence at the spot of the miraculous union. ${ }^{1}$

Sublime, Pathos, Beauty, and Proportion are all present here on the title page in a picture of the infinite universe within man:

IJune K. Singer, The Unholy Bible: A Psychological Interpretation of Wiliam Blake (New York: G. P. Putnam's Sons for the C. G. Jung Foundation for Analytical Psychology, 1970), p. 48. 
The nature of infinity is this: That everything has its

Own Vortex; and when once a travelier thro' Eternity Has passd that Vortex, he perceives it roll backward behind

His path, into a globe itself infolding; like a sun: (M 15: 21-24)

Blake, anticipating other Romantics, chooses on his title page to represent the revolutionary, inspiring forces of Hell as feminine and the passive shaping reason of Heaven as masculine. The choice is significant. Both represent aspects of the Human Form, but only one aspect is allowed to develop within an individual in the world of generation; the other is denied and repressed until it becomes a mere abstraction or Negation. Desire is perverted into jealousy, and passive form becomes timid restraint. The little boy and girl, free at first to share equally in the feminine world of the mother, are very early separated by restrictions on their behavior. The son is robbed of his right to imitate the mother, while the daughter is never offered any other example. The father for both becomes a distant other, a power to be achieved and surpassed by the boy and a forbidden authority for the girl. The boy, pushed out of the feminine atmosphere, must erect strong defences against any aspect of his personality which would cause him to reenter it and so bring on the disapproval of his mother and the wrath of his father. "So It was that society and heaven were identified with the masculine aspects of the personality, while all those 
elements that were repressed came to be associated with the feminine. "2

This divided state of self-denial might very well produce a paradise for a mystic like Swedenborg, whose concept of Heaven was of a virgin land, spotless and sterile. It was a place of negations: the regions where evil never came to life because desire was never awakened. He taught that man should bend his hopes toward reaching this void on high, that to achieve it he must deny his passion and live a life of restraint and watchful concern for his perishable soul. . . .3

For Blake, however, such a state must result in a comatose condition for the Human Form:

But the perturbed Man away turn'd down the valleys dark;

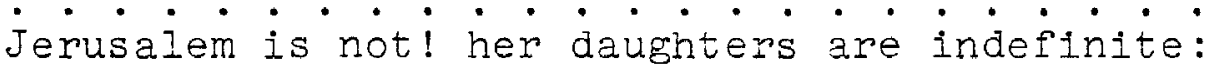

So spoke Aibion in jealois Pears, hiding his Emanation (J. $1: 22 ; 27 ; 33$ )

And Los said. I behold the finger of God in terrors! Albion is dead! his Emanation is divided from him!

(J. $12: 5-6)$

I see the Four-fold Man. The Humanity in deadly sleep

- - $\dot{0}$ Divine Spirit sustain me on thy wings!

That I may awake Albion from his long \& cold repose. (J. 15: 6;9-10)

Jerusalem is not only repressed; her existence is refuted. Iike the God of Abraham, Albion has ripped the feminine from the bosom of Man and denied the possibility of their co-existence. This Eternal Sleep which Herbert Marcuse-echoing Freud--calis "surplus repression" and identifies

$$
{ }^{2} \text { Ibid., p. } 46
$$


with thanatos (the death urge), is encouraged by society because it is sterile and therefore cannot create any threats to the established order; indeed, it cannot really create anything. This condition is the disease of civilization":

diagnosed.. as the conflict between the two basic impulses of man (the sensuous and the form impulses), or rather as the violent "solution" of this conflict: the establishment of the repressive tyranny of reason over sensuousness. Consequently, the reconciliation of the conflicting impulses would involve the removal of this tyranny-that is, the restoration of the right of sensuousness. 4

As the title page of The Marriage of Heaven and Hell gives over to "The Argument," that "disease of civilization," epitomized for Blake both by the materialism of the Industrial Revolution and by Swedenborg's mystical Heaven of sterility and denial of passions, is faced with an immediate infusion of antibodies from the Human Form Divine:

Rintrah roars \& shakes his fires in the burden'd air; Hungry clouds swag on the deep.

( $\mathrm{MHH} 2: 1-2)$

The voice of the Reprobate prophet is an inarticulate roar, but $i$ ts message is clear. The cancerous Negations must be consumed in purifying fires so that the agonized body of Man may restore itself to healtin. The wrath of the Reprobate blazes because "the perilous paths," the rightful

${ }^{4}$ Eros and Civilization: A Philosophical Inquiry into Freud, rev. ed. (New Tork: Vintage Books, 1962), pp. 173-174. 
place of the Redeemed "just man" has been usurped by the Elect villain. The sneaking serpent, with "mild humility," supplants the meek just man and separates pity and wrath with disastrous results. He "hinder[s] the just man or prolific, thereby upsetting the perfect, dynamic reciprocity (necessary and productive opposition) of the two fundamental principles of the universe. . . [T]he villain feasts on but also exhausts the fruits of a once vital culture." 5 Precisely this usurpation is recounted in greater detail in the Bard's Song of Milton.

The most frightening quality of the sneaking serpent is his "mild humanity." He binds men to error not with blatant falsehoods but rather with perverted truth:

What Blake most fears and hates is more easily defended by hypocrisy or self-deception than by frankness. "Truth," he says, "can never be told so as to be understood and not be believ'd." The inference is that falsehood can never be told so as to be understood, and not be recognized as false....

This idea that truth in a false context is worse than outspoken falsehood leads in Blake's thought to a distinction between a "contrary" and a "negation." . . In Milton Blake calls the negations "the Elect from before the foundation of the Word"; an ironic reference to the theory of predestination. . . They are the righteous whom Jesus did not call to repentance, and of whom he says with grim ambiguous irony: "They have their reward."6

$$
5 \text { Jackson, p. } 209 .
$$

6 Northrop Frye, Fearful Symmetry: A Study of William Blake (Princeton: Princeton University Fress, 1947), pp. 188-189. 
This, then, is the crisis of the age. The perspective of the world is topsy-turvey, out of balance; the perilous paths are in the hands of those who belong on the paths of ease, the active under the thumb of the passive. To the sufferers of this crisis Blake issues his apocalyptic proclamation.

The Narrator wastes no time in carrying out his mission. He proclaims the establishment of the "new heaven" and revival of "the Eternal Hell" in his very first sentence. The implication is obvious: the Messiah, the "perfect prophet," has arisen once again with his vision of Last Judgment and his purification with fires. The Angel Swedenborg has watched over him as he slept, but now the prophet has awakened, cast off the earth-bound garments of Swedenborg's writings, and emerged from the tomb to begin his ministry to the Intellectual Powers. First, however, he must establish his credentials and outline the plan of salvation.

Blake is clearly identified as the new prophet by the ironic reference to the year of his own birth as the start of the new age. He "deliberately links his own mission as poet-prophet, the reviving Hell, to the ministry of Jesus ended at thirty-three." But his "brilliant innovation is that he chooses the apocryphal version of Christ's actions after resurrection as the pattern for his work." The Gospel of Nicodemus, imposed upon the vision of 
Swedenborg, provides the context for Blake's proclamation of his own prophetic initiation:

After his revival, Christ's first act, according to the Gospel of Nicodemus, was to harrow Hell; . . . [he] descends to Hell in order to fulfill as expeditiously as possible God's promise of release to Adam and Eve, as well as a host of other faithfuls. . . Blake's imagery telescopes seemingly opposite events (descent and ascent) into a single moment and action. . . For Blake, as a matter of fact, the harrowing of Heil and the resurrection are one: his descent is his ascent; he goes into what the Religious call Hell in order to return with life-saving insights for humanity, the new Adam.

Christ sacrifices himself and enters the "Furnaces of affliction" in order to free Adam and save the new Adam. But Christ is the seed of Adam, and he is the new Adam, who, thirty-three years after his "advent," was crucified and returned "into Paradise." His action, then is to save his own Humanity by sacrificing his Selfhood. The vision of Blake's entire canon is encapsulated in this proclamation, for Albion's redemption is identical to this:

So Albion spoke \& threw himself into the Furnaces of affliction

All was a Vision, all a Dream: the Furnaces became Fountains of Living Waters flowing from the Humanity Divine

And all the Cities of Albion rose from their Slumbers, and AII

the Sons \& Daughters of Albion on soft clouds Waking from sleep.

\section{Mary V. Jackson, "Prolific and Devourer: From} Nonmythic to Mythic Statement in The Marriage of Heaven and Hell and A Song of Liberty," Journal of English and Germanic Philology, 70 (1971), p. 210. 
THE EPIPHANIC MONENT

The juxtaposition of Corporeal destruction and Intellectual redemption, "the dominion of Edom, \& the return of Adam into Paradise," is further emphasized by the reference to Isaiah 34 and 35 :

a small prophecy within a larger one . . , dealing literally and historically with the fall of Babylon but figuratively and anagogically with last things: a vision of destruction is succeeded by a vision of the new heaven and new earth. . . .

The reference to "the dominion of Edom" may be, as Damon suggests, ${ }^{2}$ an allusion to Essau, the just man cheated by his "sneaking" brother Jacob, and to the prophecy of Issaic that one day the elder brother would regain his birthright. The passage from Isaiah, though, would indicate a different reading:

The two chapters make one distinct prophecy. . . , consisting of two parts: the first containing a denunciation of Divine vengeance against the enemies of the people, a Church of God; the second describing the flourishing State of the Church of God, consequent upon the execution of those judgements. . . Among those Edom is particularly specified. . . Accordingly the

\section{IJoseph Anthony wittreich, Jr., Angel of} Apocalyose: Blake's Idea of Milton (Madison: The University of Wisconsin Press, 1975), D. 192.

${ }^{2}$ S. Foster Damon, William Blake: His Philosophy and Symbols (New York: Peter Smith, 1924), p. 316. 
Edomites were, together with the rest of the neighbouring nations, ravaged and laid waste by Nebuchadnezzar. . . .3

Edom becomes a symbol of that which must be destroyed before the kingdom of God can be achieved where no "ravenous beast shall go up thereon, it shall not be found there; but the redeemed shall walk there. . ." 4

The commentary which follows this vision of the Eternal Hell's revival is the first explicit statement of the philosophy of contraries. Nevertheless, the fact that the statement is explicit does not mean that the language is literal or, as Blake would say, Corporeal. When what Wittreich has called "the objective voice of plate $3 " 5$ says that "Without Contraries is no progression," it does not mean linear progression and most certainly does not imply industrial or Hegelian progression. "Attraction and Repulsion, Reason and Energy, Love and Hate, are necessary to Human existence." 6 Human for Blake is synonymous with Divine. Thus, the progression mentioned here is the dynamic existence of the fourfold Human Form Divine in Eden where the contraries engage in eternal Mental Warfare; that is; progression is the activity of the Imagination.

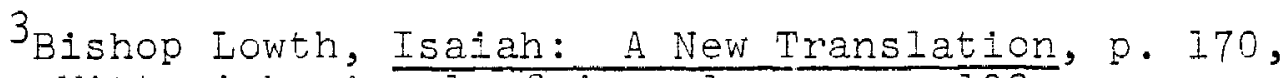
quoted in Wittreich, Angel of Apocalypse, p. 192.

${ }^{4}$ Isaiah 35:9.

5 Wittreich, Angel of Apocalypse, p. 195.

6 Italics mine. 
Furthermore, the reader must bear in mind that this "objective voice," the closest we come to the voice of Blake himself in The Marriage of Heaven and Hell, is not of the Devil's party. Ciearly the Devil, who speaks of some contraries as true and others as false, would be incapable of sighting the equal status of Reason and Energy. He could not define Good and Evil in terms of the active and passive contraries without making a value judgment as he does on plate 4. Contraries cannot be Errors, for Errors do not exist in Eden:

Blake's concern is not with making a simple inversion of usual moral categories but with reassessing them. The Marriage of Heaven and Hell is not, like the later prophecies, an exploration of evil but rather a redefinition of good through a system of contraries that, interacting, bring man to the threshold of vision. However, as Blake explains in Milton, the struggle of contraries must be redeemed by destroying the negations, which impede the progress implied by contraries.7

The importance of the philosophy of contraries cannot be underestimated in the study of Blake, particularly when one considers him as the producer of a unified canon, for the themes and symbols drawn from that philosophy permeate every element of his work. The contranies are the basis of Blake's dynamic universe. It is understandable, therefore, that a fair amount of controversy has developed over the years concerning the probable source or sources of that philosophy and the ways in which

$$
{ }^{7} \text { Wittreich, Angel of Apocalypse, p. } 193 .
$$


certain figures and symbols mentioned in The Marriage of Heaven and Hell figure into it.

Martin K. Nurni, 8 after pointing out that Blake's doctrine is not Hegelian, nor similar to that of Nicholas of Cusa, nor like the alternating principles of Yin and Yang, finally asserts that the source is Jacob Boehme, and others have agreed. Harold Bloom, 9 however, argues that Blake had no source for the contraries, while some scholars such as S. Foster Damon and Joseph Wittreich name Milton as the source. Wittreich's argument that the contraries represent a modified Miltonic element is very convincing and represents undoubtedly the best work done on the relationship of the two poets. I have presented what I believe to be the essentials of his argument below, largely in his own words, and have elaborated where our viewpoints seem to be somewhat different. Considering the Romantic poet's familiarity and identification with his great predecessor:

This notion of correspondence between individual works seems a profitable way of pursuing the relationship between the two poets, but there is no one-to-one correspondence as Damon leads us to suspect. If we are to discern the subtie knot that joins these two poets, we must see The Marriage beside Reason of Church-Government (1642), Doctrine and Discipline of Divorce (1643) and Areopagitica (1644), where Blake

" "On The Marriage of Heaven and Hell," in Discussions of William Blake, ed. John E. Grant (Boston: D. C. Heath and Company, 1961), pp. 93-101.

${ }^{9}$ Blake's Apocalypse, p. 77. 
found the presiding themes for his prose-satire, while taking liberty to alter these ideas as he saw fit. 10

\section{Blake was familiar enough with Reason of}

Church-Government to quote it from memory in his "Annotations to Reynolds," and in this work Milton raises the issues of contraries:

- Milton comments, "if we look but on the nature of elementall and mixt things, we know they cannot suffer any change of one kind, or quality into another without the struggle of contrarieties" (Yale Milton, I, 795)... When we recall the context in which Milton's statement appears, in a work that instructs England to "rub her eyes" and man to "open his eyes to a higher consideration of good and evil" ( $I, 834,836)$, in one that divides into two parts, the first celebrating the theme of liberation through contraries, the second the theme of vision through contraries, the entire work culminating in an image of mental warfare producing apocalypse-when we recall all this,...II

then we obviously will have discovered the other major context, beside the old Testament prophets and the Book of Revelation, in which Blake intended his own canon to fit. Milton offers strength and inspiration at every turn to the later poet, as well as a touchstone against which Blake could test his own insights. Theme after theme and symbol after symbol arise from the wells of biblical prophecy and flow through the conduit of Miiton's prose and epics to be refined in the furnace of Blake's imagination.

\section{0"Blake's Philosophy of Contraries: A New} Source," English Languase Iotes (December 1966), pp. 105106.

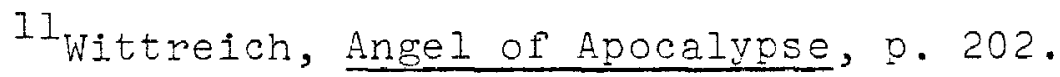


It is in The Reason of Church-Government that Milton argues against the notion that any one "party" can advance truth by suppressing dissent. "To destroy factions, to annihilate contraries, Milton concludes, is to bring 'all the diameters of schisme' together and to 'knit [them] up in the center of one grand falsehood' ( $I$, 783). . . "12 Anticipating the already quoted remarks by Marcuse (who was himself echoing Schiller), Milton continues that the Church's attempt to outlaw dissent "is the very disease we groan under; and never can be to us a remedy but by removing it selfe" (Yale Milton, I, 791). "Milton acknowledges time and again in The Reason of Church-Government that though sects and parties are limiting to vision they are necessary to perception."13

In Areopagitica Milton calls those who would suppress dissent "the troublers, . . the dividers of unity' who effect 'the forc't and outward union of could and neutrall and inwardly divided minds' (Yale Milton, II, 550-51)."14 Thus, it is the orthodox, no matter what orthodoxy they are preaching, who pervert fragments of truth and bind them into "one grand falsehood" or, as Blake would say, "One Law." Truth, like the Human Form, was at one time "a perfect shape most glorious" but was broken "into a thousand pieces, and scatter'd. . to the four winds. . Iimb from limb. . . We have not yet

$$
\text { I2Ibid., p. 203. 13 Ibid., p. 202. }{ }^{14} \text { Ibid. }
$$


found them all. . , nor ever shall we till her Masters second coming; he shall bring together every joynt and member and shall mould them into an immortall feature of lovelines and perfection." (Yale Milton, II, 549.)

We are again reminded of the remark by Marcuse when we find that

- Milton's own doctrine of contraries is prefaced, in The Reason of Church-Government, with the observation that sects and schisms are "the throws and pangs that go before the birth of reformation" (Yale Milton, I, 795) [Compare this passage with the illustration of the woman giving birth at the bottom of plate 3 and the first line of A Song of Liberty.] and followed by the reminder that "Tis not rebellion [the child referred to in the illustration and the song] that ought to be the hindrance of reformation, but it is the want of this which is the cause of that" (I, 798). It is "rebellion," the attendant strife of contraries, that in Milton's pamphlet and Blake's prophecy push

"reformation. forward with all possible dilligence and speed" (I, 800).15

Wittreich points out that even the "minute particulars" of Blake's philosophy can be found in Milton:

Milton devines Blake's contraries of love and hate - . in The Doctrine and Disciplire of Divorce, explaining that he means "not that Hate that sins, but that which onely is naturall dissatisfaction and the turning aside from a mistaken object" (Yale Milton, II, 253).

- Milton comprehends that "two contraries" can meet "their own destruction" through "a third existence - . or some evil Angel which wreaks havoc in marriages and in the world." The "third existence," he concludes, is the cause of "jarre and discord that ends in rancor and strife"; it is not a contrary, but an "opposite both to marriage and to Christianities" (II, 280).16

$$
{ }^{15} \text { Ibid., pp. 203-204. } \quad 16 \text { Ibid., p. } 204 .
$$


So it is that, with Milton, Church orthodoxy or "Prelaty - . is the negation that must be destroyed to redeem the contraries"; and with Blake it is by means of "the conception of negation," never explicitly stated in The Marriage of Heaven and Hell, that we can "comprehend the triumph over the angel that occurs at the end of his prophecy--a triumph that instead of rejecting the doctrine of contraries insures its survival." 17 When he embraces the consuming fires:

What the Angel. . relinquishes, then, is not the positive but the negative in the Christian vision; he relinquishes not action but all that impedes action and thus enables the struggle of contraries to resume. 18

Wittreich is exactly correct when he argues that Milton devoted his entire career as a polemicist to the recovery of lost truths. Armed with the weapons of truth, Mizton says in Animadversions, he can "throw down your Nebuchadnezzars Image and crumb le it like the chaffe of the Summer threshing floores" (I, 700).

But he is just slightly wide of the mark with the remarks that follow. Indeed, "Annihilating falsehood, mastering lost truths, marrying them into a unity--these are the objectives of Blake in The Marriage of Heaven and Hell"; and it is true that ". . . they are figured through 'Nebuchadnezzars Image' on its penultimate plate, an image that must be broken before the marriage state can be achieved." But it is not necessarily true that "Blake thought the Apocalypse wolid not occur until such a 
marriage had been accomplished. . . "19 Blake, and perhaps Milton also, saw the annihilation of falsehood, the embeacing of truth, and the Apocalyptic marriage as an instantaneous event

Whenever any Individual Rejects Error \& Embraces Truth, a Last Judgment passes upon that Individual. ( $\underline{\mathrm{VLJ}}, 551)$

The Apocalypse occurs ir a moment, a "Pulsation of the Artery," which is also six thousand years.

So the entire meaning of the Marriage of Heaven and Hell is laid out in the very first, most consice and obscure vision on plate 3 . The message is repeated and the symbols elaborated in the six visions and commentaries which follow.

"The Voice of the Devil" (plate 4) gives the Reprobate's view of the doctrine of contraries. Though it is far closer to visionary understanding than the pompous declarations of the Angel, it is nonetheless still a judgmental and limited view, quite unlike the objective, balanced view of plate 3. It is the philosophy of orc, the credo of the eternal revolutionary whose revolution must ultimately end in a recurrence of tyranny. Northrop Frye has called the process of this viewpoint the "Orc cycle":

As soon as we begin to think of the relation of Ore to Urizen, it becomes impossible to maintain them as separate principles. If orc represents the reviving force of a new cycle, whether of dawn or spring or

${ }^{19}$ Ibid., p. 203. 
history, he must grow old and die at the end of that cycle. Urizen must eventually gain the mastery over Orc, but such a Urizen cannot be another power but Orc himself, grown old. The same is true of the dragon: the dragon must be the hero's predecessor and the hero in his turn must become a dragon. But if the dragon is death, then when the hero dies he is swallowed by or otherwise absorbed into the dragon. . . But if the dragon is itself the old Orc, then surely is not orc simply a dragon who has the power to shed his skin from time to time? . . .20

Thus, the Voice of the Devil cannot offer a total vision of truth because it is the voice of "a god of renewed 'vegetable,' or natural human, Iife" ${ }^{2 I}$ and the "natural human" is merely the limit of contraction, not the Human Form itself. The Voice of the Devil is like the voice of Moses in Egypt, doomed eventually to petrify into the stone Law-giver of Sinai, who will in his turn be opposed by new voices of prophecy and rebellion:

The cycle finally dies in a wild cancerous tissue of huge machinery, a blankly materialist philosophy, an inner death of the soul which causes mass wars, and a passive acceptance of the most reckless tyranny. It is in these late periods that new prophets, in whom the spirit of a reviving orc is stirring, appear to proclaim a new gospel. This last phase is symbolized by the crucifixion of orc, in the form of a serpent, on the tree of mystery, the binding of human imagination to the vegetable world and the absorption of human ife into the order of nature. 22

Obviously more than the purely Reprobate view is necessary for the Apocalypse. Critics recognize this fact as essential to Blake's later works, but many fail to

20 Northrop Frye, Fearful Symmetry: A Study of William Blake (Princeton: Princeton University Press, 1947), p. 210.

$21_{\text {Ibid., p. } 207 .}$ 22 Ibid., p. 211. 
recognize that it is just as essential to The Marriage of Heaven and Hell because of their peculiar insistence that, except for the Angel with whom, they argue, he has absolutely no sympathy and even "despises,"23 every voice in the work is Blake's own voice and each line he wrote, an explicit statement of the entirety of his philosophy of the moment. So it is that singer can claim:

- Blake fails to acknowledge the necessity of enduring the tension of the opposites. Consequently he falls into a state which delights in the energetic activity of the unconscious while discrediting the governing role of reason. Here we can perceive the enantiodromia [the principle which argues that "any given position is always superseded by its negation"] in action. That Blake is still caught in the net of Swedenborgian reason is seen in the vehemence of his opposition to the views then currently accepted. 24 Mary Jackson is closer to the point when she remarks, "He takes great pains to define the active or prolific contrary because, as he has shown, it is so often denied or restrained." 25

The notion of the orc cycle, the prodigious works of the creative energies, gradually exhausted and petrified by their own timidity into specterous symbols of

23 June K. Singer, The Unholy Bible: A Psychological Interpretation of Wili iam Blake (New York: G. P. Putnam's Sons for the C. G. Jung Foundation for Analytical Psychology, 1970), p. 149.

p. 63.

$$
{ }^{24} \text { Ibid., p. 66; the definition is quoted from }
$$

25 Mary V. Jackson, "Prolific and Devourer: From Nonmythic to Mythic Statement in The Marriage of Heaven and Hell and A Song of Liberty," Journal of English and Germanic Philology, 70 (1971), p. 211 . 
restraint, struggling to enslave their own former strength and any new manifestations of it, and the ultimate apocalyptic end to the cyclical pattern are elaborated in the commentaries on plates $5-6 ; 11 ; 14 ; 16-17$; and 21-22. The first and last of these deal with the two representatives of Energy and Restraint, Milton and Swedenborg, and all of them are concerned with the relationship of "sensual enjoyment," artistic creation, and prophetic vision. "It is by means of the metaphoric relationship between sexual delight and artistic expression that he moves from the discussion of Desire versus the Restrainer to his judgment on Paradise Lost. "26

The criticism of Milton leveled on plates 5 and 6 is perhaps the single most troublesome passage in The Marriage. The difficulties of interpretation, however, generally arise once more from the reader's unwillingness to deal with the work as other than a tract. The passage is, first of all, a commentary on the vision of plate 4 , and it is delivered from the infernal point of view in the context of a history of the universe; there is nothing to distinguish the speaker of plate 4 , clearly identified as "The Voice of the Devil," from the speaker of plates 5 and 6. The tone and viewpoint remain the same, and we may assume that the "Voice" does also as the other voice did

$$
26 \text { Ibid., p. } 212 .
$$


between the vision and the commentary on plate 3. The Devil, on plate 4, has somewhat misrepresented the Angel's position, and he continues to do so on the following two plates:

Christianity, traditionally, asserted the neutrality, not the evilness, of the body, though some sects, notably the Puritans, moved in the direction the Devil suggests, giving to his perspective a measure of validity but not redeeming it from partiality. Moreover, there is the insinuation here that Milton conforms to orthodox lines as the Devil draws them, when, in fact, Milton. . acknowledges the delights of the body as openly as Blake does and, in Paradise Lost, revolutionizes the story of the fall by introducing sexuality, approvingly, to the garden before the fall occurs. In this sense, then, the Devil's critique is misleading, and it has also proved misleading by inviting the inference that Satan is Milton's hero. Whatever else these plates may say, they do not say that Satan is the hero of Paradise Lost. ${ }^{2}$

Remembering that it is spoken by the Devil, who equates the terms Desire and Imagination, and that it is in the context of a view of history, exactly what preoccupies the final books of Paradise Lost, we can now begin to get at the meaning of Blake's famous criticism. At least part of the criticism is leveled against what is generally regarded as a fading of the brilliance of imagination (for the Devil, Desire) brought on by the restricting and most unpoetic subject matter of those final books. Wittreich quotes the representative opinion of the eighteenth-century critic Thomas Newton:

27 Wittreich, Angel of Apocalypse, p. 210. 
The reader may have observed that these last two books fall short of the sublimity and majesty of the rest; and so likewise do the two last books of the Iliad, and for the same reason, because the subject is of a different kind from that of the foregoing ones. The subject of these two last books of the Paradise Lost is history rather than poetry. 28

Simply put, Milton the poet was restrained by Milton the biblical historian. The energy which permeates the earlier books, where his scriptural source material is its slimmest and therefore his poetic freedom its greatest, is greatly diminished when he is faced with a bulk of orthodox history. But the terms of the Devil are not aesthetic; they are sexual. Therefore, he accuses Milton of writing the history of restrained desire. On the Devil's side it could be further argued that the subject of that history is the gradual decline of the visionary element of man and his continual sinking into a materialistic preoccupation until at last both he and his former Paradise are inundated by the ultimate symbol of materialist chaos, the Deluge. However, no one ever claimed that Blake's Devil is a fool or a liar; he is simply partisan and therefore somewhat limited in his perspective:

- - when Satan, the reservoir of divine energy, is expelled, Godhead falls, and Christ loses his energy, becoming a "ratio of the five senses," a reasoning circumference rather than a center of energy. Reason

${ }^{28}$ Ibid.; Wittreich quotes from Paradise Lost, ed. Thomas Newton, 9th ed., 2 vols. (London: J.F. and C. Rivington, 1790), II, pp. 449-447. 
divorced from energy is impotent, and energy by itself is formless. The fallen perspectives related to these interpretations and represented in The Marriage of Heaven and Hell by the Devil and the Angel are limiting, for each has become identified with a "party." 29

The Devil's ironic remarks are justified because the Messiah of Paradise Lost is, indeed, an impersonal, youthful sky god, unquestioningly executing the laws and punishments of his ancient and even more impersonal father. Given these facts about him, it is not at all unreasonable to conclude that "in the Book of Job Milton's Messiah is call'd Satan." In later years Blake did a series of interpretive illustrations to the Book of Job; so his familiarity with it is not to be questioned. The significance of his understanding of this book cannot be overestimated because "the Eible as a whole was to Blake an epic of the fall and redemption of man . . ," and the "thing that Blake clearly saw in the story of Job was a microcosm of the whole biblical story." 30 Job's three friends and Elihu argue the orthodox view which, whether because of the restrictions of seventeenth-century English censorship, a wish to avoid unduly upsetting an all too orthodox audience, or a temporary failure of vision, color

\section{${ }^{29}$ Wittreich, Angel of Apocalypse, p. 211. \\ 30 Northrop Frye, "Blake's Reading of the Book of} Job," in William Blake: Essays for S. Foster Damon, ed. Alvin H. Rosenfeld (Providence: Brown University Press, 1969), p. 221. 
Milton's theology in matters heavenly and so damage his dilineation of the divine personages:

- . the assumption underlying the religion of the three friends was that moral and natural laws are administered by the same God. For Blake, of course, this was "natural religion," and nonsense. . . Anyone who associates human and natural law is trying to make the latter the model of the former, eliminating everything unpredictable from human behavior and with it everything that makes for a free and creative human community. Persistently through history man has projected his gods. . . He continualiy tries to invent a God who is a philosophical first cause, a personal guarantor of the mindless order of nature. - . As long as an obedient moral life is associated with a comfortable physical one, this deity may look providential and benignant. But when the crunch comes he turns into Satan, the sense of littleness and futility that makes us accept any kind of misery as somehow ultimately just, or at least, inevitable. Thus for Blake Satan and the God he consults with at the opening of the book are two aspects of the same God. 31

Certainly Blake is not alone in his observation. Alan Watts writes in his The Two Hands of God (New York: George Braziller, 1963) that the problem is inherent in the very notion of a projected deity who is the omnipotent embodiment of absolute goodness, for the "sine qua non of absolute goodness is absolute evil. . . There is not the least doubt that Hell is unqualified, absolute, and unimaginable evil." Because these principles are not simply different but rather polar extremes of a moral spectrum, however, the two embodiments of those principles actually serve to define each other, and, therefore, "the reality of the two is the unity which lies implicitly 
between them." Thus, the entire cosmic arama of the war in heaven takes on the nature of the scene which begins Job. It becomes a "'big act' whereby the universe scares itself stiff for the thrill of it. For it is as if in the far-off beginning, behind the scenes, before the world drama began, the Lord and the Devil had agreed to have a battle, like Tweedledum and Tweedledee--their agreement being in their inexpressible, unmanifest, and their ineffable unity." 32

In Job, as Blake saw it and perhaps as the original author saw it also, there is an even more bizarre twist, for God is seen relinquishing his authority over humanity to his younger, more energetic, irresponsible counterpart:

Satan is clearly younger than God, and they seem to be related much as Father and Son are in Paradise Lost, God being the weak, sick dieu faineant of Plates 2 and 5 resigning his power to his own demonic Messiah. Many years earlier Blake had remarked in The Marriage of Heaven and Hell that "in the Book of Job, Milton's Messiah is call'd Satan" (PI. 5, K 150). Blake here was thinking partly of the Son's activity in spoiling his own creation in Book $X$ of Paradise Lost (technically Sin and Death spoil it, but the Creator cannot abdicate responsibility so easily), and then destroying it altogether in the Flood. 33

Thus, viewed ironically and within the context of the Book of Job, the Devil's remarks are not as outlandish as they at first seem, for they point to a problem of vision, inherent at the beginning of the Book of Job, at the end of

${ }^{32}$ Quoted in Singer, p. 79.

33 Frye, "Blake's Reading of the Book of Job," p. 227. 
Paradise Lost and in the depiction of the Father and Son in that work, and in the perspective of the Devil himself. His comments about who threw whom out of Eternity and Christ's calling for "Desire" to get Ideas underscore this point. He says, in effect, that those disposed to interpreting data in completely different ways will view a single event in two opposed manners. If one always equates energy and desire; then an appeal for strength and comfort must necessarily be viewed as a call for desire. This is the subject of every one of the Memorable Fancies. The Devil's statement that "after Christs death, he became Jehovah" emerges like the rest from his concentration on Corporeal history and, in this case, puts him directly at odds with the view of his creator. For Blake, Christ returns from the desert and "emerges a perfectly integrated personality, having cast aside the law of obedience for the gospel of love." 34 Much the same happens to Job, and his conception of the godhead is therefore quite different at the end of his story. Milton's Paradise Regained, a purely visionary work which Blake revered and which the Devil would not criticise in even a gentle, ironic manner, deals entirely with just this emergence of the divine, integrated personality during the desert temptations of Christ. "After his death, he does indeed return to the Father; and the Father becomes like 34 Wittreich, Angel of Apocalypse, p. 212. 
the Son rather than the Son's becoming like him: the God of Wrath, Jehovah, becomes a God of Mercy, Jesus." This "eternal perspective," however, is not shared by the Devil, who

advances his critique from the perspective of history rather than eternity; and consequentiy what he says is historically, but not eternally, true. This distinction, drawn by Blake himself, is also recognized by Hazard Adams when he says that to crucify Christ upside down "means that Blake believes the historical development of Christianity has been toward the reassumption of an all-surrounding. . . abstract moral law. Thus the historical christ of the modern church is the upside-down man, while the upright Christ is the perpetually immediate visionary act." 35

The Devil's "Note" is the absurd extreme to which his entire line of commentary has inevitably led him. It is ridiculous to accuse Milton of being "a true poet. . without knowing it." of course, Blake believed that Milton was a "true poet," that is a Prophet, but he believed just as strongly that the statement, "Poets \& Prophets do not know or Understand what they write or Utter. . . is a most Pernicious Falshood." (VLJ, 544) If Milton was indeed a Reprobate, and Blake would argue that he was, then he was totally conscious of the fact. He may have suffered occasionally under the yoke of orthodoxy, but such lapses were only temporary. His canon declares him as a bold revolutionary.

35 Ibid.; Wittreich is quot:no Uarard Adams, William Blake: A Reading of the Shorter Poems (Seattle: University of Washington Press, 1963), p. 44 . 
The most frequently employed symbol in The Marriage of Heaven and Hell, and one of tremendous importance to the entirety of Blake's canon, is fire. The Devil reminds us that Jehovah was originally perceived as a fire god; three of the Memorable Fancies and one of the Commentaries employ the image; and many of the illustrations picture individuals springing from or reveling in flames. When the Narrator speaks of "walking among the fires of Hell," he is referring to the pure energy of unrestrained Imagination which makes art possible. Blake's repeated reminders of his own corrosive method of printing point to the link he recognized between fire and craftsmanship. Words are often symbolically connected with fire, but in Blake the whole concept of fabrication is inextricably related to fire. He therefore falls into the tradition shared by the Ancients, whose god of craftsmanship, Hephaestus or Vulcan, was also the god of fire, by the Hebrews, who saw their prophets' lips purified by burning coals, by Christ, who spoke of the baptism of fire, by Dante, who saw that in Paradise "the fire and the rose are one," and by Milton, whose architect Mulciber is pictured as a blazing meteor when he, like Hephaestus, is cast from heaven:

. . thrown by angry Jove Sheer o'er the crystal battiements: from morn To noon he fell, from noon to dewy eve, A summer's day, and with the setting sun Dropped from the zenith like a falling star. 
Perhaps the most astonishing association of fire to visionary perception which lay at Blake's disposal is the miracle of the fiery furnace in the Book of Daniel where the four major philosophical principles of Blake's visionary awakening are fused with the archetype of the Furnace of Los:

Then Nebuchadnezzar the king was astonished, and rose up in haste. He said to his counselors, "Did we not cast three men bound into the fire?"

They answered the king, "True, O King."

He answered, "but I see four men loose, walking in the midst of the fire, and they are not hurt; and the appearance of the fourth is like a son of the gods. "I6

Northrop Frye recalls the relationship of fire to sexuality when he writes, "The resurrection of the body means the resurrection of all the body, and as the physical body has a sexual origin, the sexual life, Blake says, becomes a human one, which means sex is transformed, not eliminated. In eternity, Blake remarks dryly:

Embraces are Cominglings from the Head even to the Feet,

And not a pompous High Priest entering by a secret Place." 37

This, then, is the "improvement of sensual enjoyment," which will signal the end of time and bring about the Apocalypse at the close of six thousand years. It is also identical to the description of angelic love-making given

$$
\begin{aligned}
& 35 \text { Daniel } 3: 24 \text {; italics mine. } \\
& 37_{\text {Frye, Fearful Symmetry, pp. 195-196. }}
\end{aligned}
$$


to Adam by Raphael in Paradise Lost. Thus:

Paradise itself is a place of flaming fire, the fires being the "lustful" passions which there are fully gratified. They are also "thought-creating Iires" because gratified desire produces reason. Eden is a fiery city, as is indicated in Ezekiel's speech to the Covering Cherub: "Thou hast been in Eden the garden of God. . . thou hast walked up and down in the midst of the stones of fire." 38

The symbol of fire is the presiding element in the two most forthright dramatizations of Blake's notion of the Imagination as it functions in the mind of the artist-visionary and the contrary "party" perceptions of that Imagination. I am speaking, of course, of the Memorable Fancies relating the Printing house in Hell (plate 15) and the journey tinrough the two views of the cosmos (plates 17-20). Both visions are actually descriptions of the same thing, for in the Printing house Blake describes "the mind itself according to the principle of interacting contraries," 39 and "in the long view the journeys of the Angel and the narrator use al the principles and powers of the first seventeen plates to herald the fundamental principle of human perception, . . . explicitly stated. . 'All that we saw was owing to your metaphysics. . . "40 Each vision takes place in six

$$
\begin{aligned}
& 38 \text { Ibid., p. } 196 . \\
& 39 \text { Jackson, p. } 213 . \\
& 40 \text { Morris Eaves, "A Reading of Blake's Marriage of }
\end{aligned}
$$
Heaven and Hel1, Plates 17-20: On and Under the Estate of the West," Blake Studies, 4 (Spring 1972), p. 81. 
chambers or stages, corresponding to the six thousand years which make up the span of Corporeal time and account for a "Pulsation of the Artery." Together they make clear:

- . that the significance of the conclusion to

Plate 11--"Thus men forgot that All deities reside in the human breast"--resides in the distinction between man's Imagination containing the universe and being contained by it. The contained universe is ruled by Jesus the Imagination, the containing universe by Mother Nature in one of her sacred guises. 41

The Printing house allegory, then, is a picture of the "contained universe" drawn by a member of the Redeemed. It shows a Human universe in which the various forces remain in their appropriate chambers and carry out their appropriate functions. This is Mental Warfare creating, and the result is also a portrayal of the creation of a work of art: "The five allegoric creatures (as well as the five senses) are the 'Giants who formed this world into its spiritual existence,' the mysterious, unnameable sources of spiritual energy." 42 Remembering this implied relationship of man's senses, the "narrow chinks of his cavern," to "the method in which knowledge is transmitted from generation to generation," we find what may at first seem to be an incredible parallel in "The Epistle to the Reader" which opens, of all things, John Locke's Essay Concerning Human Understanding and in which the author declares:

$$
\begin{aligned}
& { }^{4 I_{\text {Ibid. }}, \mathrm{p} .82 .} \\
& 42 \text { Jackson, p. } 215 .
\end{aligned}
$$


- In an age that produces such masters as the great Huygenius and the incomperable Mr. Newton, with some others of that strain, it is ambition enough to be employed as an under-laborer in clearing the ground a little, and removing some of the rubbish that lies in the way to knowledge. . . .43

The man who spoke of the sense organs as "posterns" allowing "admittance" of ideas to "the nerves which are the conduits to convey them from without to their audience in the brain,--the mind's presence-room (as I may so call it), "44 offers a description of the perception of Blake's falien man which the poet could hardly improve upon:

- . I think it is not possible for any man [Blake would say fallen man.] to imagine any other qualities in bodies, howsoever constituted, whereby they can be taken notice of, besides sounds, tastes, smells, visible and tangible qualities. And had mankind been made but with four senses, the qualities then which are the objects of the fifth sense had been as far from our notice, imagination, and conception, as now any belonging to a sixth, seventh, or eighth sense can possibly be;--which, whether yet some other creatures, in some other parts of this vast and stupendous universe, may not have, will be a great presumption to deny. . . I have here followed the common opinion of man's having but five senses; though, perhaps, there may be justiy counted more. . . 45

Small wonder Locke finds a place equal to Milton's at the close of Jerusalem. He may have been bound by the chains of ratiocination, but he was not completely beaten by them.

In the mind of the reintegrated individual, the dragons of "primordial . . creative force" clear the

43 John Locke, An Essay Concerning Human Understanding, ed. Maurice Cranston (London: CollierMachilian, Lta., 1965), p. 23.

$$
44 \text { Ibid., p. 67. } \quad 45 \text { Ibid., } 0.71 .
$$


rubbish and hollow the cave, "Blake's way of saying that the mind makes a start or beginning, clears a 'space' in which to create," while the vipers of unfallen reason determine "its periphery or olitward bound, defining (or delineating its form" and add embellishments. The eagle of Imagination makes infinite the perspective, and the lions of expression give it substance which can be transmitted. "Finally, the unnamed forms . . . shape the creative impulse, which is now represented by molten living fluids, and cast it into the expanse where 'Men,' the conscious mind with which man usually identifies himself, receive them as communicable cultural forms." 46 The process is visually illustrated by the picture of the eagle's soaring aloft carrying the viper in his talons. The Imagination makes the perception of the liberated Reason infinite. In addition, the Printing house Memorable Fancy can be viewed in a more specific manner as a visionary description of Blake's engraving process. Both views reveal an interesting parallel with the journey of the Angel and the Narrator and a relationship with the symbolism which marks Blake's later works:

The chambers of the printing house follow the progression of a work of art in illuminated printing from initial engraving to storage in a library. The chambers of the houses of religion follow the progress of Westem intellectual history from the birth of Christ to Blake's time: from the stable (the

$$
46 \text { Jackson, pp. } 214-215 \text {. }
$$


primative Christianity of those present at the birth of Christ) to church (the Middle Ages) to mill (the "natural religion" of Enlightenment rationalism, called "systematic reasoning" [pl. 21] in The Marriage) 47

What we are shown in the Memorable Fancy of this journey is first the Angel's and then the Narrator's perception of these chambers. What is to the Angel a "hot burning dungeon" is to the Narrator "the enjoyments of Genius," and what to the Narrator are monkey houses are to the Angel the mills of orderly reasoning. The Narrator is aware of this fact, as his remark about the Angel's metaphysics makes clear, but the Angel is not. His lack of understanding is obvious when he "speaks with the hysterical urgency of moral confusion," ranting in a naive "Sunday-school Jacobean diction. After all, not even Isaiah and Ezekiel dine to the tune of 'thou art' and 'thyself." 48 The Narrator and the reader can only be amused by this time at the tirade of the Ancel because both, having seen the Printing house in Hell, have learned that "Energy is Eternal Delight."

In sum, then, the diabolical reading of the Angel's warning is this: "Consider the work of art, the fiery acids and the burning copper, which you are preparing for yourself, which can end oniy in an Eternity of delight toward which your career is carrying you at full speed." No wonder the narrator stays cool. 49

$$
\begin{aligned}
& 47 \text { Eaves, p. } 84 . \\
& 48 \text { Ibid., p. } 82 . \\
& 49_{\text {Ibia., p. } 83 .}
\end{aligned}
$$


What the two witness bears this reading out, for

- . the vision that the Angel's metaphysics are controlling is a heavenly version of the picture at the bottom of plate 15, the printing house allegory, where a "Power of the Air" (the eagle) holds his prey (in the terrific shape of an animal sprung from corruption). 50

So the eternal lot of the Narrator (and, for that matter, the lot of the Angel) is in the realm of his own Imagination, "because Last Judgments are intellectual events, and the center of energy [the 'black but shining' sun] in any Last Judgement is the mind." 51

With this realization in mind, we move to the final vision of The Marriage of Heaven and Hell, one which consumates the promised marriage and precisely indicates the future course of Blake's career, particularly in his final great epics, Milton and Jerusalem. The Devil and the Angel, confronting one another at last, argue their differing perceptions of the central figure in Blake's mythology, Jesus Christ. The Angel, given over at last to the energies of his wrath, "Rejects Error \& Embrases Truth." His Negation is consumed in the fires of Self Annihilation, and he arises as Elijah. But the important point to this reading, one of the most significant in The Marriage, is that the Narrator "beheld" the consummation:

And Elijah took his mantle, and wrapped it together, and smote the waters, anc they were divided hither and thither, so that they two went over on dry ground.

${ }^{50}$ Ibid., p. 89.

${ }^{51}$ Ibid., p. 107 . 
And it came to pass, when they were gone over, that Elijah said unto Elisha, Ask what I shall do for thee, before I be taken away from thee. And Elisha said, I pray thee, let a double portion of thy spirit be upon me.

And he said, Thou hast asked a hard thing: nevertheless, if thou see me when I am taken from thee, It shall be so unto thee; but if not, it shall not be so.

And it came to pass, as they still went on, and talked, that, behold, there appeared a chariot of fire, and horses of fire, and parted them both asunder; and Elijah went up by a whirlwind into heaven.

And Elisha saw it,. . . and he took hold of his own clothes, and rent them to pieces.

He took up also the mantle of Elijah that fell from him, and went back, and stood by the bank of Jordan; And he took up the mantle of Elijah that fell from him and smote the waters, . . and when he had also smitten the waters, they parted hither and thither: and Elisha went over. 52

\section{Blake has presented his credentials and demon-} strated his authority as a prophet. He has taken up the mantle of his own Elijah, the poet-prophet John Milton, and he will bind it on himself like a sandle to smite the waters of materialistic chaos so that he may pass over at last into the vision of Eden in Jerusalem. 
CHAPTER IV

TO PROPHESY THE WAYS OF GOD TO MAN

The vision which closes The Marriage of Heaven and Hell becomes the material for epic treatment in Milton. In the later work Blake, as a character as well as the narrator, witnesses the purification of his Elijah figure, Milton, and receives the mantle of Milton's prophecy and a double share of his prophetic spirit, for he is joined in his being both by the purified Milton and by Los, the "Shadowy Prophet" himself, "the ever apparent Elias." Thus strengthened, Blake begins in earnest the mission he has publicly dedicated himself to in The Marriage of Heaven and Hell and reaffirms in the Preface of this epic, paradoxically both the agency and the first fruit of his transformation, created when he smites the waters of materialism and causes them to part and reveal the dry path to the land on the other side. As in The Marriage of Heaven and Hell, the overriding themes of Milton are the purgation and consummation, brought about through self-sacrificial descent leading to prophetic union.

The context and tradition of the poem are made clear on the title page and elaborated in the Preface, lyric, and quotation of plate 2. Not only is this a poem 
about Milton, it is one which is meant to fit squarely into the biblical, prophetic tradition to which the revolutionary Milton adhered. Further, it draws its major themes, structure, central conceit, and, indeed, its singular purpose from that tradition. The declaration "To Justify the Ways of God to Men" and the Preface are obvious in their Miltonic echoes, but exactly how far these echoes reach is not at first apparent:

The Preface delineates Blake's objective in writing Milton, which is to further the cause of freedom in every department of life and art, while celebrating the glory of the English nation in whose green and pleasant land Jerusalem will be built. Milton, of course, provides Blake with a precedent for celebrating the English as the second chosen people and the poet as their deliverer. He began Paradise Lost by equating England with Israel and himself with Moses. 1

The attack on the art of Ancient Greece and Rome ("The Stolen and Perverted Writings of Homer \& Ovid") and the celebration of the inspirational art of the bible and of those who followed--albeit imperfectly--in that tradition, likewise has a precedent in both the manifesto which precedes Paradise Lost and the invocations to Books VII and IX of that epic, as well as in the arguments of Christ in Paradise Regained, where Milton's language is (understandably) similar to Blake's own.

\section{${ }^{I}$ Joseph Anthony wittreich, Jr., Angel of} Apocalypse: Blake's Idea of Milton (Madison: The University of Wisconsin Press, 1975), D. 239. 
Not alone in the epics, however, do precedents appear for Blake's remarks. Milton had raised virtually every issue of plate 2 in his earlier prose works. As Wittreich points out:

In The Reason of Church-Government, celebrating mental warfare as "the approved way which the Gospell prescribes," Milton urges the use of "spiritual weapons" for "warfare, not carnal1, but mighty through God to the pulling downe of strong holds, casting down imaginations, and every high thing that exalteth it selfe against the knowledge of God" (Yale Milton, I, 848). . .

In Defensio Secunda, Milton exalts himself as mental warrior above the common soldier, explaining that defending truth by intellect is more noble than defending it by arms. . . No one, says Milton, should believe "it more glorious to smite the foe than to instruct himself and others in the knowledge of heavenly things, or think it more noble to practice warlike rather than the evangelical combat" (IV, $i$, $648) .2$

Wittreich's citations are revealing, but there is

an even more striking passage in Areopagitica:

Lords and Commons of England, consider what Nation it is wherof ye are, and wherof ye are the governours: a Nation not slow and dull, but of quick, ingenious, and piercing spirit, acute to invent, suttle and sinewy to discours, not beneath the reach of any point the highest that human capacity can soar to. Therefore the studies of learning in her deepest Sciences have bin so ancient, and so eminent among us, that Writers of good antiquity, and ablest judgement have bin perswaded that $e^{\prime} v$ n the school of Pythagoras, and the Persian wisdom took beginning from the old Philosophy of this Iland (Yale Milton, II, 551-552).

Having established that England is the ancient and original seat of learning and art--and thereby, considering his

$$
{ }^{2} \text { Ibia., pp. } 241-242 .
$$


later remarks in Paradise Regained, et al., having made explicit his own identification of England and Israel-Milton turns to the spiritual significance of the island and so implicitly identifies his own cosmic importance as the nation's self-annointed poet-prophet:

Yet that which is above all this, the favour and love of heav'n we have great argument to think in a peculiar manner propitious and propending toward us. Why else was this Nation chos'n before any other, that out of her as out of Sion should be proclam'd and sounded forth the first tidings and trumpet of Reformation to all Europ. And had it not bin the obstinat perversnes of our Prelats against the divine and admirable spirit of Wicklef, to supresse him as a schismatic and innovator, perhaps neither the Bohemian Husse and Jerom, no nor the name of Luther, or of Calvin had bin ever known: the glory of reforming all our neighbours had bin compleatly ours. (Yale Milton, II, 552-553)

With supreme confidence and romantic egocentrism, mixed with a touch of rhetorical humility, Milton concludes:

Now once again. . God is decreeing to begin some new and great period. . . : what does he then but reveal Himself to his servants, and as his manner is, first to his English-men; I say as his manner is, first to us, though we mark not the method of his counsels, and are unworthy. (Yale Milton, II, 553)

Certainly the author of Areopagitica would have little difficulty understanding and appreciating the accusation of the "silly Greek \& Latin slaves of the Sword," whose "Stolen and Perverted Writings" have "curb'd by the general malady" even the works of Shakespeare and himself, the confident declaration that "all will be set right," the rousing call to the "Young Men of the New Age" who will set their "foreheads against the ignorant 
Hirelings," and the bold declaration:

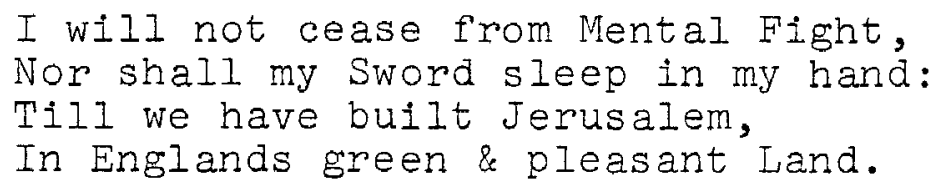

Finally, in that same pamphlet, Milton hearkens back to Numbers $11: 29$ and forward to Blake's lyric when he proclaims :

Let us therefore be more considerat builders, more wise in spirituall architecture, when great reformation is expected. For now the time seems come, wherein Moses the great Prophet may sit in heav'n rejoycing to see that memorable and glorious wish fulfill'd, when not only our sev'nty Elders, but all the Lords people are become Prophets. (Yale Milton, II, 555-556)

Blake's epic theory is likewise drawn from the pronouncements of Milton and built upon the models of the Bible and Paradise Regained. As Wittreich, reminds us in his essay, "Opening the Seals: Blake's Epics and the Milton Tradition," Blake's epics are prophecies and therefore take place entirely in an instant: "Iike God in Book III of Paradise Lost, the prophetic poet sees all aspects of time--past, present, and future--collapsing into a single moment." 3 (Wittreich's essay provides the best available treatment of Blake's concept of epic and its relation to prophecy. Vogier offers a different but not, I think, altogether incompatible approach in his

3"opening the Seals: Blake's Epics and the Milton Tradition," in Blake's Sublime Allegory: Essays on the Four Zoas, Milton, Jerusalem, ed. Stuart Curran and Joseph Anthony Wittreich, Jr. (Madison: The University of Wisconsin Press, 1975), p. 47. 
Preludes to Vision. Wittreich should be read to establish Blake's place at the end of a tradition, Vogler to place him at the beginning of a new one. The conclusion one is apt to draw is that Blake occupies a point on a continuum of literary theory and tradition, a thought which seems perfectly reasonable to me but which likely would not have amused T. S. Eliot.) Paradise Lost, particularly in Book VI wherein Raphael attempts to describe to Adam the creation of the cosmos, makes some effort to deal with the prophetic moment, but Raphael relies entirely upon a linear narrative structure and sequential terminology. Thus, he makes himself clear to the Corporeal Understanding but obscures the Imaginative Understanding. Such attention to the Corporeal Understanding would prevent Paradise Lost from serving as a model for Blake's own epic, which "observes Milton's dictum, enunciated in Defensio Secunda, that the epic poet should undertake 'to extol, not the whole life of the hero.. . but usually one event of his life,' as well as Milton's corresponding suggestion that if the purpose is to celebrate a nation, then the orator or poet should settle upon 'one heroic achievement of . . . [his] countrymen' (Yaie Milton, IV, 1, 685)." 4

Fortunately, Blake did not have to rely upon Paradise Lost as a model, for: "Out of the epic ruins of Paradise Lost, Milton created a new form, free of the ${ }^{4}$ Angel of Apocalypse, p. 243. 
impedimentia of convention and distinguishable by the union achieved between epic and prophecy. "5 From Pareus Milton learned to employ prophetic structure as demonstrated in Revelation to combine tragic and epic structures:

Tragedy and epic alike view the same experience but respond differentiy to it. . . . Like Job and Paradise Lost, the Book of Revelation has its tragic story, but it also culminates in a moment of triumph that succeeds the cycles of defeat. In this sense-and in the sense that Revelation has the cosmic dimensions of no other scriptural book--it is a suitable model for epic, especially as Milton came to understand the genre. Shorter than the ordinary epic, the brief epic, as exemplified by Paradise Regained, had to rely upon typology to create its encyclopedic compass, but the brief epic also magnified the dramatic element in the diffuse epic--and magnified it so greatly that the brief epic poem became an intensely dramatic poem, the interest of which was psychological and the structure of which was created by contending perspectives (the various interpretations of Christ's baptism) and by a. series of gradually sharpening antitheses (the confrontations between Christ and Satan) that culminate in the vision on the pinnacle, in the moment when Christ apprehends his divinity and when Satan, smitten with amazement, exposed for what he is, falls. 6

This prophetic epic structure, of course, is

followed exactly by Blake in Milton as well as in Jerusalem. Northrop Frye has correctly asserted of the two epics, "Milton is an individual prologue to the omen of something universal coming on. The Last Judgment lies on the distant horizon, and is prophesied in the final line of the poem. . . Jerusalem deals with the complementary awakening in man and the full apocalypse. One is

\footnotetext{
5 "Opening the Seals," p. 34.

Ibid., p. 35 ; italics mine.
} 
resurrection and the other Last Judgment, corresponding to the first and second coming of Jesus." 7 Blake, like Milton before him, saw Jesus as the supreme visionary, the "perfect prophet." Thus the struggle of any prophet is a type of that of Jesus himself: "Despite its surface complexity, Milton demands simply and relentlessly that the incarnation, passion, and resurrection of Christ be repeated in every man." 8 Blake further saw with Milton precisely what most eighteenth-century readers of Paradise Regained could not see (and for that reason found much fault with the poem); Paradise is regained for Man in that exact moment when Christ resists the temptation of Satan and rejects utterly the static, petrifying Selfhood which the demon represents. The passion and resurrection become inevitable in the instant that Christ recognizes and accepts his mission, and so the central struggle and sacrifice for salvation comes not on the cross, or even on the Mount of Olives, but on the pinnacle above Jerusalem: "A poem about the formation of the prophetic character, Paradise Regained (as well as Blake's tenth illustration

\section{Northrop Frye, Fearful Symmetry: A Study of} William Blake (Princeton: Princeton University Press, 1947), pp. 323-324.

'James Rieger, "'The Hem of Their Garments': The Bard's Song in Milton," in Blake's Sublime Allegory: Essays on the Four Zoas, Milton, Jerusalem, ed. Stuart Curran and Joseph Anthony Wittreich, Jr. (Madison: The University of Wisconsin Press, 1973), p. 270. 
for it) locates visionary maturity in the culminating moment of the third temptation. Now, having become a prophet, having perfected his visionary capacity, Christ may take up his ministry--he may begin to prophesy": 9

The descent into the underworld is modulated into Christ's descent into himself; the descent of the heavenly messenger is modulated into Christ's willing descent from the pinnacle to begin the work of man's redemption. The first descent brings the hero into the presence of the divine vision; the second effects its extension to mankind. The same conventions, similarly combined and transformed, are incorporated into Milton, where the hero, like Christ descends into himself to annihilate selfhood and, accomplishing that, descends into the world (into Blake's garden) to become its Awakener. 10

Descent and union, then, are the governing actions of Milton, from the opening lines in which Blake invokes the Daughters of Beulah to

Come into my hand

By your mild power; descending down the Nerves of my right arm

From out the Portals of my Brain, where by your ministry

The Eternal Great Humanity Divine, planted his Paradise." (2:5-8)

to the final union of Milton and Ololon in which

with one accord the

Starry Eight became

One Man Jesus the Saviour. (43:10-11)

In the invocation an Eternal vision descends to the Corporeal world of the generated poet, who naturally p. 118 .

${ }^{9}$ Wittreich, Angel of Apocalypse, p. 295--note to ${ }^{10}$ Ibid., p. 119. 
complains throughout of his inability to record the vision with accuracy:

O how can I with my gross tongue that cleaveth to the dust,

Tell of the Four-fold Man, in starry numbers fitly orderd

Or how can I with my cold hand of clay! But thou 0 Lord

Do with me as thou wilt! for I am nothing, and vanity.

$(20: 15-18)$

James Rieger explains the poet's difficulty as follows:

Rhetorically, Milton exists on four levels of discourse, corresponding to the four worlds of Blake's myth. The highest voice is, of course, the sublime of pure vision, the Edenic mode of the Bard's Song. The lowest is the False Tongue, the sense of touch, equivalent to "Ulro, Seat of Satan" (27:45-46). Between them lie the voice of the Daughters of Inspiration in Beulah and, beneath that, the language of

"Albions land: / Which is this earth of vegetation on which now I write" (14:40-4I). The utterances of any higher realm are only partially intelligible to the inhabitants of the worlds below it. That is the central stylistic problem of the poem.II

In order to achieve a higher level, the generated poet must willingly commit himself to the state of Annihilation of Selfhood, which happens to be Milton, the pcem itself as much as the character, more so in fact, since the character himself is not the State:

Distinguish therefore States from Individuals in those States.

States Change: but Ircividual Identities never change nor cease:

You cannot go to Eternal Death in that which can never Die.

Satan \& Adam are States Created into Twenty-seven Churches

And thou 0 Milton art a State about to be Created

${ }^{1 I_{\text {Rieger, }}}$. 277. 
Called Eternal Annihilation that none but the Living shall

Dare to enter: \& they shall enter triumphant over Death

And Hel1 \& the Grave: States that are not, but ah! Seem to be.

Judge then of thy Own Self: thy Eternal Lineaments explore

What is Eternal \& what Changeable? \& what Annihilable!

The Imagination is not a State: it is the Human Existence itself[.]

$(32: 22-32)$

Thus, curiously, Milton must descend to Blake in order for Blake to expand to the level of Milton's composition:

Milton's path of descent is . . . a re-examination of the roles of Love and reason in his life and art (as he passes between Urizen and Luvah), a confrontation with Satan (through his fires), and a return to his Adamic State (the limit of contraction and the destination of his "track") to unite with his redemptive emanations. I2

The Individual in that Adamic State with whom Milton joins is Blake, and the point of union is Blake's foot, which, we were informed in The Marriage of Heaven and Hell, represents Proportion, the property of Tharmas, who is also water, the symbol of materialistic chaos which incrusts the collapsed bubble of the fallen fourfold man. Thus, Blake's "bubble" is expanded first by the injection of Milton and then by that of Los. The mantle of prophecy appears as a sandle smiting the material waters; the bubble expands and

\section{Irene Taylor, "Say First! What Mov'd Blake?} Blake's Comus Designs and Milton," in Blake's Sublime Allegory: Essays on the Four Zoas, Milton, Jerusalem, ed. Stuart Curran and Joseph Anthony Wittreich, Jr. (Madison: The University of Wisconsin Press, 1973), p. 253 . 
consumes the incrustations, and the fourfold vision is regenerated in Blake.

Throughout the epic there is a recurrent pattern of shifting perspectives from inspiration to inspiration. The Daughters of Beulah inspire Blake the narrator to give voice to the Bard, whose Song begins the work and occupies about a third of its plates. The Bard's Song expands into a cosmic, prophetic perspective view of history and then "returns to the bosom of Milton. . ."13 Milton's journey again opens up the cosmic perspective and then compresses it into the physical being of Blake. This naturally opens the Imaginative perspective of Blake to the cosmic when Los also joins with him. The end of Book I expands to a vision of the work of the Sons of Los, "a vision of the time-world"; ${ }^{14}$ and then focuses on the moment of Inspiration:

For in this Period the Poets Work is Done: and all the Great

Events of Time start forth \& are concievd in such a Period

Within a Moment: a Pulsation of the Artery.

Such is the World of Los the labour of six thous and years.

Thus Nature is a Vision of the Science of the Elohim. $(29: 1-3 ; 64-65)$

13 Thomas A. Vogler, Preludes to Vision: The Epic

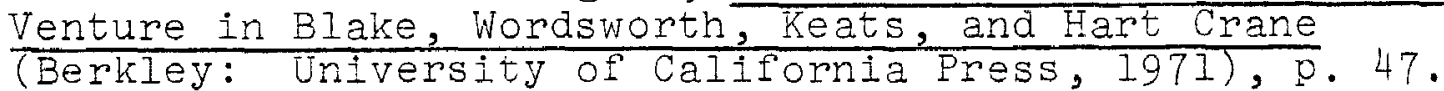
14 Wittreich, Angel of Apocalyose, p. 237. 
The cosmic perspective returns with the descent of Ololon during that very same moment (35:42-47). Ololon eventually appears in material form before the "Vegetated portion" of Blake, again returning the perspective to the earthly (36:13-20). However, we are informed that the move to Felpham and the patronage of Hayley have been dictated by Los as a furtherance of the poet's prophetic powers:

For when Los joind with me he took me in his firy whirlwind

My Vegetated portion was hurried from Lambeths shades He set me down in Felphams Vale \& prepard a beautiful Cottage for me that in three years I might write all these Visions

To display Natures cruel holiness: the deceits of Natural Religion[.]

Walking in my cottage Garden, sudden I beheld The Virgin Ololon \& address'd her as a Daughter of Beulah.

$(36: 21-27)$

Thus, by now even the Vegetated perspective of the poet has been opened up to the eternal, cosmic view (36:28-31). Ololon's appearance before Biake precipitates the penultimate expansion of vision to the cosmic perspective in which Blake witnesses the destruction of the consolidated Selfhood $(37: 44-46 ; 39: 1-2)$ and the emergence of the Human Form Divine within his own Imagination

(42:7-23). Again he returns to the mortal perspective "To Resurrection \& Judgment in the Vegetable Body" (42:27). The final lines of the epic are given over to Los, Rintrah, and Palamabron as they prepare for the ultimate expansion of cosmic vision in which the Human Form Divine will awaken 
entirely in all men and "All the Lords people" will become prophets. The entire process is rather like breathing, with each breath taking in more and purer air.

The Bard's Song, a pure vision conceived in the Eternal perspective and translated (more or less) into the language of generation, is understandably difficult, so difficult, in fact, that critics often yield to "the easier task" of interpreting it as historical (Erdman) or biographical (Bloom, Damon, et al.) rather than as Sublime Allegory. James Rieger draws the shortcomings of such approaches perfectly:

To say that Palamabron, toiling in the Satanic mills, suggests Blake illustrating Hayley's ballads is to note an actual resemblance; but it is not to make a valid critical statement. One can as meaningfully apply the myth to the experience of past or "future generations." When Palamabron labors out of his vocation, he looks like Milton sacrificing bodily and spiritual vision as Cromwli's Latin Secretary, or like any steward of the Word who hides his talents. It is, for instance, methodologically proper to speculate that Elynittria's chastity and jealousy explain why "my Shadow of Delight. . . is sick with fatigue" (36:31-32); whether or not Elynittria is an eternal type of the vegetated Shadow, the Shadow is herself a character in the poem, not the historic Catherine Blake. But it is falacious (as well as the loosest chatter about the dead) to assert, even as cautiously as Damon did, that Mrs. Blake's "arrows of jealousy kill inspiration," or that Leutha is "the personification of iayley's unconscious homosexuality."15

Such strained interpretations miss entirely the Bard's own stated purpose for his song, repeated like a chorus throughout:

$$
{ }^{15} \text { Rieger, pp. } 261-262 \text {. }
$$


Mark well my words! they are your eternal salvation! The eternal salvation of any individual is dependent upon the assumption of the prophetic perspective with its concommitant recognition and rejection of Error. Therefore, the subject and purpose of the Bard's Song must be identical to those of the rest of the epic, the prophetic perspective. As Rieger has said, "The Bard's Song. . Is a prophet's account of the fall of prophecy itself, Los 'the Spirit of Prophecy the ever apparent Elias' (24:71)."16 This reading gathers support when one recalls that the conflict within the song is between the three Classes of Men, who are "Created by the Hammer of Los, \& Woven / By Enitharmans Looms" $(2: 26 ; 3: 1)$. Enitharmon, also, is a creation of Los, for she is his Emanation. Indeed, every character in the Song is a creation of Los; most of them are directly identified as his sons or daughters. Even Urizen fits into this grouping, having been given what form he has in his fallen condition by Los, who "became what he beheld" (3:28) and so (in a sense) actually created himself. So it is that the song records a continual division and decimation of the prophetic spirit. Los is himself the fallen form of Urthona, and the Sons of Los divide not only from him but, ultimately, from one another as well in the contest for Palamabron's Harrow. 
The "perfect prophet" it will be recalled combines both pity and wrath with love, but among the divisions of Los, pity and wrath have become separated, and even love is susceptible to perversion. Only if each child of Los keeps to his or her proper station can any semblance of harmony be maintained. When Satan begins to counterfeit his brothers, devastating confusion results which completely clouds the prophetic vision. 17 Two of Los' "four mighty ones," Theotormon and Bromion, contend "on the side of Satan / Pitying his youth and beauty" (8:30-31), and stand against their two counterparts, Palamabron and Rintrah. Palamabron certainly has contributed to the problem in more than one way. His daliance with Satan's Emanation Leutha produces the lure which, we learn later, draws into "the Generations of Tirzah" (24:6) all but the "four mighty ones" of Los:

In dreams she bore Rahab the mother of Tirzah \& her sisters

In Lambeth vales;

$(13: 41-42)$

and his fearful unwillingness to show anger and so prevent the usurpation of his Harrow produces equally disasterous results. Because Palamabron does not protest and point out his father's mistake, Los is deceived by Satan's "pretence of pity and love" $(7: 26)$. Palamabron accepts "the easier

17 Much of my reading here is indebted to Rieger, pp. $264-273$. 
task" (8:5), forgetting Los' warning to Satan:

If you account it Wisdom when you are angry to be silent, and

Not to shew it: I do not account that wisdom but Folly.

$$
(4: 6-7)
$$

Neither Satan nor Palamabron is suited for the task he undertakes, and so everything is thrown into chaos. Ironically, Los' initial response is that Palamabron should have known better:

So Los said, Henceforth Palamabron, let each his own station

Keep: nor in pity false, nor in officious brotherhood, where

None needs, be active.

"Los scolded Palamabron because he could not yet see that he himself had erred by giving in to the 'most endearing love' of Satan (7:5)."18 Eventually, of course, the recognition of the magnitude of his own guilt dawns upon Los as he exclaims: "Mine is the fault! I should have remember'd that pity divides the soul / And man, unmans" (8:19-20). The Error which began for Los with the binding of Urizen has finally become recognizable in the perversion of pity and love by Satan.

The method by which pity and love are redeemed ( $I$ choose the word carefully.) is a curious one. Satan has perverted them and thrown the world of Los--that is, as we shall discover later, the Time world--into aisarray; yet

$18_{\text {Rieger, p. } 265 .}$ 
paradoxically it is Rintrah who receives the condemnation of the Assembly. Rintrah has stood against Satan and infected him with his rage; the results of this infection are staggering:

Then rose the Two Witnesses, Rintrah \& Palamabron: And Palamabron appeal'd to all Eden, and recievd Judgment: and Lo! it fell on Rintrah and his rage: Which now flam'd high \& furious in satan against Palamabron

Till it became a proverb in Eden. Satan is among the Reprobate.

For Satan flaming with Rintrahs fury hidden beneath his own mildness

Accus'd Palamabron before the Assembly of ingratitude! of malice:

He created seven deadly sins drawing out his infernal scroll,

Of Moral laws and cruel punishments upon the clouds of Jehovah

To pervert the Divine voice in its entrance to the earth

With thunder of war \& trumpets sound, with armies of . disease

Punishments \& deaths musterd \& number'd; Saying I am God alone

I have brought them from the uppermost innermost recesses

of my Etemal Mind, transgressors I will rend off for ever,

As now I rend this accursed Family from my covering.

Thus Satan rag'd amidst the AssembIy! and his bosom grew

Opake against the Divine Vision: the paved terraces of His bosom inwards shone with fires, but the stones becoming opake!

Hid him from sight, in an extreme blackness and darkness,

And there a World of deeper Ulro was open'd, in the midst

of the Assembly. In Satans bosom a vast unfathomable Abyss.

And Satan not having the science of Wrath, but only of Pity: 
Rent them asunder, and wrath was left to wrath, \& pity to pity.

He sunk down a dreadful Death, unlike the slumbers of Beulah.

$$
(9: 8-12 ; 19-35 ; 46-48)
$$

The judgment falls upon Rintrah, but it is Satan who undergoes the self-inflicted imprisonment, which resembles nothing so much as solipsistic paranoid schizophrenia. The choice of the Assembly has been condemned by most mortal critics, and even in heaven:

. . It was enquir'd: Why in a Great Solemn Assembly The Innocent should be condemn'd for the Guilty? Then an Eternal rose

Saying. If the Guilty should be condemn'd, he must be an Eternal Death

And one must die for another throughout all Eternity.

Satan is fall'n from his station \& never can be redeem'd

But must be new Created continually moment by moment And therefore the Class of Satan shall be calld the Elect, \& those

Of Rintrah. the Reprobate, \& those of Palamabron the Redeem'd

For he is redeem'd from Satans Law, the wrath falling on Rintrah,

And therefore Palamabron cared not to call a solemn Assemb ly

Till Satan had assum'd Rintrahs wrath in the day of mourning

In a feminine delusion of false pride self-deciev'd.

So spake the Eternal and confirm'd it with a thunderous oath.

$(11: 15-27)$

I do not sense any irony in the inspired Bard's choice of the word confirm'd. He, at least, in spite of Harold Bloom, seems to agree with the Eternal's theodicy. Indeed, it sounds rather like the decision in a similar "trial" related by yet another English poet-prophet in 


\section{Book III of Paradise Lost:}

Behold mee then, mee for him, life for life I offer, on mee let thine anger fall; Account mee man; I for his sake will leave Thy bosom, and this glorie next to thee Freely put off, and for him lastly die. Well pleas'd, on me let Death wreck all his rage; . .

So Man, as is most just,

Shall satisfie for Man, be judg'd and die, And dying rise, and rising with him raise His Brethren, ransomd with his own dear life. So Heav'nly love shall outdo Hellish hate, Giving to death, and dying to redeem, So dearly to redeem what Hellish hate So easily destroy'd,. . .'

$$
\text { (III, 294-30I) }
$$

Rieger employs the Eternal's speech as a means of elucidating the account of the trial:

It appears that "Pintrah," the rage that flamed high and furious in Satan after judgment was given, had been annexed by him in the day of mourning that preceded the trial, when both had burned "angry red" over the plowed fields. 19

Rieger refers to the following passage:

But Rintrah who is of the reprobate: of those form'd to destruction

In indignation. for Satans soft dissimulation of friendship!

Flam'd above all the plowed furrows, angry red and furious,

Mill Michael sat down in the furrow weary dissolv'd in tears.

Satan who drave the team beside him, stood angry and red.

$(8: 34-38)$

Recognizing his opportunity in this infection of Satan with wrath, the clever lawyen Palamabron

$$
\text { I9 Ibid., p. } 267 .
$$


- . seized this opportunity to compel Satan "to/ Defend a Iie, that he may be snared \& caught \& taken" (8:47-48). Rintrah appeared as a trial witness not in his own person, but as a self-defeating irateness "in" Satan the adversary. Satan raged even higher after the verdict because, although the "Rintrah" in him had borne the brunt of the judgment, he himself had been cast out for safe-keeping in the class of Election. This is to say that whereas honest wrath must suffer in atonement for the Satan who can so corrupt it, the corrupter himself is likewise hurled down. When Leutha offers herself as ransom for Satan's sin, she does so because she has "beheld Satans condemnation" (11:28). Wrath, a quality as chameleonic and dangerous as pity, spreads from the judged to infect the judges as well: "Los in his wrath curs'd heaven \& earth," and the Eternal reveals that the "judgment" falling on Rintrah was itself "wrath."20

When the Eternal declares that "Satan is fall'n from his station \& never can be redeem'd," he is referring to Satan the state, not Satan the Individual, for

Then Los \& Enitharmon knew that Satan is Urizen Drawn down by Orc \& the Shadowy Female into Generation. $(10: 1-2)$

Satan most certainly will be redeemed because until Urizen is reincorporated into his proper station, the fallen Albion can never be regenerated. What is more:

The Elect shall meet the Redeem'd. on Albions rocks they shall meet

Astonish'd at the Transgressor, in him beholding the Saviour.

And the Elect shall say to the Redeemd. We behold it is of Divine

Mercy alone! of Free Gift and Election that we live. Our Virtues \& Cruel Goodnesses, have deserv'd Eternal Death.

Thus they weep upon the fatal Brook of Albions River. $(13: 30-35)$

$$
{ }^{20} \text { Ibid., pp. 267-268. }
$$


Satan the Individual will be redeemed by grace, but Satan the State of Eternal Death, "Newtons Pantocrator weaving the woof of Locke" (4:II), Satan the Selfhood must be annihilated. Here, then, is the explanation for the destruction of the Angel at the close of The Marriage of Heaven and Hell which has puzzled Joseph Wittreich ${ }^{2 l}$ and misled many other commentators. The Angelic State of the Individual is obliterated when the wrath of the Devil infects him and makes his Error recognizable. But the flames he embraces consume only his Elect Selfhood, leaving untouched and purified his Individuality (after all, this is the first time any of the Angels is given a specific name). 22 The trial scene of Milton simply elaborates this point.

Palamabron is redeemed and Satan contained by the judgment of Rintrah. Pity and love are purified by the descent of wrath:

Rintrah's expiation of Urizen's Satanic guilt dramatizes the profound paradox that defines BIake's Christianity. The elect of this world and the pharisees of natural religion despise, reject, and execute the Messiah as a reprobate, a transgressor and "an Abettor of Criminals," whom it nevertheless pleased the Lord to bruise, in Isaiah's words (53:10). The Eternal in the Bard's Song appears to be saying that the true Christian virtues are fallen and tainted, that one aspect of them has petrified into what are

\section{${ }^{21}$ Wittreich, Angel of Apocalypse, p. 198. \\ ${ }^{22}$ The parallel to Act 3 , scene 3 of siegfried} and the final moments of Götterdämerung should be obvious. 
later called the "Idol Virtues of the Natural Heart" (38:46) and the accusation of sin. On the one hand, there is the just wrath of such a prophet as Jeremiah, of Jesus driving the money changers from the temple, of the Lamb returning in judgment on the Last Day, and of the lion, whose wrath is the wisdom of God (MHH 8:36). On the other, there is that of the falien Urizen, "the satanic desire to murder opposition," in Damon's apt phrase, God Almighty who "comes with a Thump on the Head." This form of wrath becomes the deadly ira, just as false pity and love are subspecies of acedia. 23

The Bard ends his Song with an account of the confession and self sacrifice of Leutha and the resultant naming of the "Mercy of Eternity," personified by the central agent of Blake's mythology:

So Leutha spoke. But when she saw that Enitharmon had Created a New Space to protect Satan from punishment; She fled to Enitharmons Tent \& hid herself. Loud raging

Thunderd the Assembly dark \& clouded, and they ratify'd The kind decision of Enitharmon \& gave a Time to the Space,

Even Six Thousand years; and sent Lucifer for its Guard.

But Lucifer refus'd to die \& in pride he forsook his charge

And they elected Molech, and when Molech was impatient

The Divine hand found the Two Limits: first of opacity, then of Contraction

opacity was named Satan, Contraction was named Adam. Triple Elohim came: Elohim wearied fainted: they elected Shaddai.

Shaddai angry, Pahad descended: Pahad terrified, they sent Jehovah

And Jehovah was leprous; loud he call'd, stretching his hand to Eternity

For then the Body of Death was perfected in hypocritic holiness,

Around the Lamb, a Female Tabemacle woven in Cathedrons Looms

He died as a Reprobate. he was Punish'd as a Transgressor!

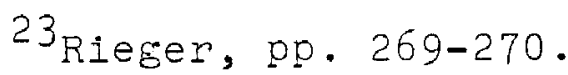


Glory! Glory! Glory! to the Holy Lamb of God

I touch the heavens as an instrument to glorify the Lord!

$(13: 12-29)$

The descent of Time and the descent of the sacrificial Lamb of Love are here, as elsewhere, equated. To borrow a commonplace, "Nothing cures like time and love."24

This point is central to all of Blake's work and can hardly be overemphasized. The Lamb, of course, is Jesus, "the Divine Body" which is "the Human Imagination" (3:3-4), but Imagination is also Los, "by mortals nam'd Time" (24:68), the creator of the universe and the Mundane Egg $(34: 31)$. In The Marriage of Heaven and Hell, Blake informs us that "AlI deities reside in the human breast" (pI. 11), and Ezekiel says, "we of Israel taught that the Poetic Genius (as you now call it) was the first principle and all others merely derivative" (pI. 12). Los is "the first principle" and in derivative form resides in every "human breast." To understand the distinction between "the first principle" and the "derivative" form, one must understand visionary time:

Visionary time is not so much a segment of a uniformly divided line as it is a quality of perception . . . [, $]$ the imaginatively informed present which has pressed upon it the imaginatively appropriated past and the imaginatively envisioned future. . . What is permanent about eternity is the nature of change. - . Something is eternal for Blake only when it is capable of continually participating in time's flow as a renewing factor. . . In fact, the essential

24 Laura Nyro, "Time and Love." 
point about a transition from time as a sea to time as eternity is creative transformation. . . .25

"Creative transformation," naturally, is the craft of Los, the master of Time ("the Mercy of Eternity") and Space (his Emanation):

The blow of his Hammer is Justice. the swing of his Hammer: Mercy.

The force of Los's Hammer is eternal Forgiveness.

$$
\text { ( J, } 88: 49-50)
$$

Having thus identified Los as Imagination, the master of Time and Space, the agent of Justice, Mercy, and Forgiveness, it should come as no surprise to us when, at the climactic moment of Jerusalem:

Then Jesus appeared standing by Albion as the Good Shepherd

By the lost Sheep that he hath found \& Albion knew that it

Was the Lord the Universal Humanity, \& Albion saw his Form

A Man. \& they conversed as Man with Man, in Ages of Eternity

And the Divine Appearance was the likeness \& similitude of Los.

$$
(\underline{J}, 96: 3-7)
$$

Los is the logos, the word of God that both creates and redeems the universe, and Jesus is the Word made flesh, One Man, Los incarnate. Milton is the latest and greatest Son of Los, but there can now be little doubt as to who Blake considered himself to be:

25 Ronald L. Grimes, "Time and Space in Blake's Major Prophecies," in Blake's Sublime Allegory: Essays on the Four Zoas, Milton, Jerusalem, ed. Stuart Curran and Joseph Anthony wittreich, Jr. (Madison: The University of Wisconsin Press, 1973), pp. 65-66. 
And Los behind me stood; a terrible flaming Sun:

just close

Behind my back; I turned round in terror, and behold. Los stood in that fierce glowing fire; \& he also stoop'd down

And bound my sandals on in Udan-Adan; trembling I stood Exceedingly with fear \& terror, standing in the Vale of Lambeth: but he kissed me, and wishd me health. And I became one Man with him arising in my strength T'was too late now to recede. Los had enterd into my soul:

His terrors now posses'a me whole! I arose in fury \& strength.

$(\underline{M}, 22: 6-14)$

Of course, he said as much ten years earlier on plate 3 of The Marriage of Heaven and Hell, while still living, by the way, in "the Vale / of Lambeth."

The first stage of Los' incarnation in Blake (The action of the poem is instantaneous in the eternal perspective, but the various aspects of it are hierarchical and so are arranged in a sequence.) is the inspiration of Milton. The Bard really enters into Milton's bosom through the agency of his Song, but he does so literally when the other Eternals fail to understand that pity and love can be perverted to evil. Milton, of course, has understood and so incorporates the Bard into himself: "The effect on Milton is the effect desired by a prophetic visionary: an awakening." 26 Therefore, as has been made clear by now, the Bard's Song is a microcosm of the purpose of the entire poem. It purifies the vision of one man and prepares him to do the same to others, i.e., make them

$$
{ }^{26} \text { Vogler, p. } 43 .
$$


prophets, also. It is both a vision and a stimulus for expanded vision, exactly what Milton as a whole is meant to be.

Milton's response is to recognize his own Error in abandoning his Emanation Ololon, while the Nations still practice Corporeal War. His stern doctrine of virginity in Comus, his tendency to create Delilah figures while refusing to create a Beatrice, and his Satan's prefunctory dismissal of women as an unworthy temptation for Christ, while nevertheless placing great stock in gluttony spiced with the hint of pederasty, are examples of his separation from his Emanation. Comus, in fact, is the work which many critics believe Blake had in mind in selecting the vehicle of Milton's reunion with Ololon. Irene Taylor, argues that Blake's work on illustrations for Comus directly inspired him to "correct" Milton's vision in an epic:

The illustrations to Comus . . are directly concerned with certain strengtins and sterilities in Milton's vision. I suggest that Blake chose Comus because at this time of renewed, attentive excitement, he saw the masque freshly as a kind of synopsis of Miltonic vision and error: further, that his work with the designs, in turn, ied him to recognize the need for a far more powerful, broader, and more deeply personal confrontation with the older poet--in short, that these designs moved him to undertake his great prophecy Milton; and finally that the residue of their influence is clearly visible in the prophecy itself, and especially so in the visionary forms of its conclusion. 27

27 Irene Taylor, pp. $234-235$. 
Taylor concludes:

Ololon is a fulfilled version of the lady of Comus as she is a maiden seeking fuller humanity, which Milton refused her in the conscious argument of his poem. But he undermines his own intention by his powerfully visionary Attendant Spirit, who shoots from Heaven "Swift as the Sparkle of a glancing Star" (1.80), as did Milton himself in Blake's vision. And Milton grasped far better than he knew the powers of the magic root haemony, that true and loyal messenger of Los. So Ololon is also in an important sense the product of Milton's own prophetic imagination, whose form Blake has not so much created as clarified.28

This point, naturally, is one of which Blake was consciously aware because 0lolon is Milton's Emanation, and the Emanation is a part of an individual's total Humanity, which Blake defined as Imagination. The conclusion of Taylor's essay is appropriate to this discussion:

She is Milton's bride, but ultimately also the Bride of the Lamb and all mankind whose name entitles Blake's final prophecy--Jerusalem. The prim virgin of Milton's Comus has come a long way; but as she achieves the fulfilled "Liberty" displayed on the final plate, so does her prophet-creator who loved Blake in childhood and "shew'd [him] his face"; Blake can at last in good conscience write "Finis" to his answering labor of spiritual warfare and brotherly love.29

Taylor makes several good points in her essay, but her notions that Blake's chief purpose in turning to an epic about Milton was to correct his predecessor's views of sexuality and that his choice was brought on by his work on the illustrations to Comus are, I believe, wrong. First, the passage relating Blake's meeting with 0lolon (36: 21-37:3) indicates that Los joined with the poet while he

$$
{ }^{28} \text { Ibid., p. } 258 . \quad{ }^{29} \text { Ibid. }
$$


was still living in Lambeth (cf. 22:9-1I) before he ever began work on his first Comus series. The implication is that the single Moment of Eternal Time related in the poem is manifested in two moments of earthly time. Second, Blake's epic is written as a celebration much more than as a correction. Certainly, the great poet of the seventeenth century had Errors to cast off (as did Blake), and he does so in the course of the epic (as does Blake). However, Milton is chosen not for his failings but for his greatness. He is the latest and greatest Son of Los, and he is the first among all the fruits of the generated world to cast off his Selfhood and reintegrate with his Emanation. Blake has chosen him for the singular honor of setting in motion the regeneration process which will lead ultimately to the Apocalypse in Jerusalem. What happens in Milton can easily be viewed as a Sublime Allegory of the effects of a great artist's work on an equally artistic and truly receptive reader. The vision of the former is purified and strengthened by the latter, and vice versa. Easily as much as correcting him, Blake is rescuing Milton from the Sons of Albion, lesser descendants of their great visionary father, who fail to grasp the meaning of the inspired Song and fall instead to legalistic nit-picking about its minute particulars.

Such a tendency to focus too heavily upon historical or biographical allegory simply leads a reader into 
Corporeal criticism and leads one away from the psychological, visionary nature and purpose of the poem. As Vogler argues :

As Blake, at a point when he felt ready to dedicate himself to his epic, met the Urizenic force of Hayley and society, so Milton encounters Urizen directly after his inspiration. Blake realized that the real struggle was not with Hayley, but with himself, and the encounter between Milton and Urizen is another version of that encounter. 30

It is the struggle of Job as BIake saw it, and it is also the struggle depicted in Blake's Miltonic original,

Paradise Regained:

- . Blake wishes. . to stress that it is only through repetition of Christ's experience, only through a corresponding journey to the very center of being, that spiritual vision is achieved. Paradise Regained Involves the gradual awakening of Jesus to his mediatorial offices and culminates in a general acknowledgment of his divinity. . . . [W] Then Milton says that he will sing of an event left "unrecorded... through many an age," he presumably refers to a story whose full significance is unattended to by Matthew, Mark, and Luke and to one linmentioned by John. Paradise Regained is written, then, as an elaborate commentary on one moment in Christ's Life, a moment which Milton invests with new significance. In the process, a new story is told. . . Paradise Regained is, after all, a new revelation. . . If the Son, as he stands on the pinnacie, can be said to assert "his continuity in the prophetic lire. . by standing in relation to Mosaic dispensation as commentator to text," then Milton, in process of writing this poem, can be said to stand in a comperable relationship to his "acknowledged sources". . . .31

Blake, too, having declared himself a prophet in The Marriage of Heaven and Hell, asserts "his continuity in the

$$
\begin{aligned}
& { }^{30} \text { Vogler, p. } 49 . \\
& { }^{31} \text { Wittreich, Angel of Apocalypse, pp. 123-124. }
\end{aligned}
$$


prophetic line" in Milton by literally following in the footsteps of his predecessor.

Four times in the course of Book I Blake's perspective returns to focus on his own left foot. In this way he reminds us that all that occurs in that Book takes place in a single visionary moment and, what is more, that "the poem's action must be read as indicative of changes taking place within Blake. At those places in the poem where the perspective opens out Blake is not changing the subject, but showing historical events as parallels to and potential effects of changes in the microcosm of his imagination." 32 on plate 21, immediately after Blake binds on the sandal of Milton's inspiration, Ololon recognizes the significance of Milton's sacrifice and decides to follow his example. As a result, the events of Book II are shown to be simultaneous with those of Book I, for her descent is not recorded until the second book and her union with Milton delayed until the end of the epic when he at last completely overcomes his selfhood. "The actual encounter between Milton and Ololon must wait, because the simultaneity is like that of a logical proposition in which all the steps exist at once yet have a definite order of priority." 33

Milton must of necessity engage in the internalized struggle with and humanize Urizen and that struggle must 
also disturb the trance-like sleep of Albion because it takes place within Albion himself and Milton's goal lies "behind Satans Seat":

Now Albions sleeping Humanity began to turn upon his Couch;

Feeling the electric flame of Miltons awful precipitate descent.

Seest thou the little winged fly, smaller than a grain of sand?

It has a heart like thee; a brain open to heaven \& hell,

Withinside wondrous \& expansive; its gates are not clos'd,

I hope thine are not: hence it clothes itself in rich array;

Hence thou art cloth'd with human beauty 0 thou mortal man.

Seek not thy heavenly father then beyond the skies: There Chaos dwells \& ancient Night \& Og \& Anak old: For every human heart has gates of brass \& bars of adamant,

Which few dare unbar because dread $0 \mathrm{~g}$ \& Anak guard the gates

Terrific! and each mortal brain is walld and moated round

Within: and $O g$ \& Anak watch here; here is the Seat of Satan in its Weos; for in brain and heart and loins Gates open behind Satans Seat to the City of Golgonooza

Which is the spiritual fourfold London, in the loins of Albion.

$(20: 25-40)$

The fact that the cosmic struggle is not only over Man, but in him as well, is emphasized by the subject of the closing plates of Book I:

The Bellows are the Animal Lungs: the Hammers the Animal Heart

The Furnaces the Stomach for digestion. . .

Bowlahoola is the stomach in every individual man. $(24: 58-59 ; 67)$

Los' control of the physiological functions of digestion, respiration, and circulation demorstrate again his control 
over Time and Space because these systems are the biological modes of measurement, and they are metaphorically linked to our astronomical modes of measurement:

As to that false appearance which appears to the reasoner,

As of a Globe rolling thro Voidness, it is a delusion of UIro

The Microscope knows not of this nor the Telescope. they alter

The ratio of the spectators organs but leave objects untouchd

For every Space larger than a red GIobule of Mans blood.

Is visionary: and is created by the Hammer of Los And every Space smaller than a Globule of Mans blood. opens

Into Eternity of which this vegetable Earth is but a shadow:

The red Globule is the unwearied Sun by Los created

To measure Time and Space to mortal Men. every morning. Bowlahoola \& Allamanda are placed on each side

of that Pulsation \& that Globule, terrible their power. $(29: 15-26)$

Again we return to the central conceit of Blake's poetry, seen here as "that Pulsation \& that Globule": the ever growing circle, the expanding globe, the bubble of imaginative humanity. The expansion of consciousness enables man to view his own humarity in cosmic terms and the cosmos as an expression of his humanity. Such expansion entails and is caused by the purgation of the limitations of his own materialistio seli-centeredness:

As the crucible-furnace-blacksmith imagery, Los's quest within the fallen human form, and Milton's exploration of his eternal lineaments all indicate, Blake's purgatory is to be found in man's vision of his own interior life. If he reaches paradise, it will have been achieved only through an intense and imaginative 
effort of self-recreation or illumination. Milton records this experience by being this experience. 34 Vogler points out in a note 35 that the "regeneration of Los in bk. I" is inextricably connected "with Milton's abandonment of Selfhood in bk. 2. . . ." Despite, as he concedes, the total lack of textual evidence that Blake consciously intended to imply "that when Los becomes prophet, loss becomes profit," the critic's pun is so delectible it bears repeating.

Book II of Milton completes the unification and expansion of perspectives begun in Book I and ends with a single flash of perfect vision. Such a flash is all that is necessary to insure the coming of the Apocalypse. The focus of the book, leading up to that visionary flash, rests with 0101 on and the three elements of nature introduced during the lament over her descent, and these elements, along with $01010 n$, speed the epic and the reader to the culmination of the identification (unification) process begun in the Bard's Song. Ololon, of course, is the Emanation of Milton and therefore the totality of his efforts (the work of his love), but she is also a creation of Blake and therefore a portion of his efforts. Yet the inspired Blake is also a portion of Milton's efforts, as

34 Edward J. Rose, "Blake's Milton: The Poet as Poem," Blake Studies, 1 (Fall 1968), p. 35.

${ }^{35}$ Vogler, p. 52. 
well as the creator of the Milton of Milton. Furthermore, both poets are the work of Los, while Los is a work of Blake.

The Nightengale and the Lark further complicate matters. The Nightengale seems to inspire the Lark, which in turn inspires the Choir of Day. The Lark's "Iittle throat labours with inspiration" ( $31: 34)$, and it is the messenger of Los. Thus, we might well assume that the Nightengale represents the poet and the Lark his poem. The difficulty is that Blake, Milton, Los, and the Bard are all poets, each inspiring the other. When one speaks of Blake as poet, one is tempted to think of Milton as a poem, and in the case of Milton as poet, Jesus himself becomes a poem. In addition, Blake, Milton, and the Bard are all messengers of Los and so worthy to be called "mighty Angels." Finally, the Lark sings in the morning:

All Nature listens silent to him \& the awful sun Stands still upon the Mountain looking on this little Bird With eyes of soft humility, \& wonder love \& awe.

$(31: 36-38)$

Peter Alan Taylor ${ }^{36}$ reminds us of a similar passage in Paradise Regained:

and now the Herald Lark

Left his ground-nest, high tow'ring to descry The morn's approach, and greet her with his Song.

\footnotetext{
36 peter Allen Taylor, "Providence and the Moment in Blake's Milton," Blake Studies, 4 (Fall 1971), pp. 54-55.
} 
As lightly from his grassy Couch up rose Our Savior.

$$
\text { (II:279-283) }
$$

Milton (in Milton) first perceives Jesus as "A disk of blood distant" (14:27), but Blake perceives him at the end of the poem in human form wrapped in a garment of blood. The image of the wild Thyme serves to make sense of this maze of interconnections, partially because it is a pun:

The Wild Thyme is Los's Messenger to Eden, a mighty Demon

Terrible deadly \& poisonous his presence in Ulro dark Therefore he appears only a small Root creeping in grass

Covering over the Rock of Odours his bright purple mantle

Beside the Fount above the Larks nest in Golgonooza Iuvah slept here in death \& here is Luvahs empty Tomb ololon sat beside this Fountain on the Rock of Odours,

The Wild Thyme is a Messenger of Los; so it is associated with Blake and Milton and the Bard. Further, as Taylor reports:

Etymologically, the word thyme is derived from a Greek verb meaning "to offer a Bacrifice," and Luvah is the form of Jesus seen as a sacnificial victim. . . "In Ulro dark," the organic unity of the Wild Thyme is seen fragmented into flower, roct and odor. From this erroneous point of view, the conjunction of ololon with the Wild Thyme can only be seen as the "harlot" aspect of the natural world comined with the creeping serpent, a combination which is the incipient form of the "Dragon red \& hidden Harlot." Seen as an agent of Providence, however, 010 lon receems the abandoned grave clothes as she appears in the form of the red clouds surrounding returned Jesus who is no longer the sacrificial Luvah. 37

37 peter Taylor, po. 56-57. 
Finally, Wild Thyme is a pun for Wild Time, the name of Los. In the moment of the visionary flash, the bewildering maze is seen for what it is: a circle, a globe, a bubble. Ololon, the Bard, Milton, Los, and even Blake are seen in the single figure of the blood garbed Jesus as he appears in Revelation the moment before Apocalypse. The last words of ololon make clear the single way of bringing on that Apocalypse:

Thou goest to Eternal Death \& all must go with thee So saying, the Virgin divided Six-fold \& with a shriek Dolorous that ran thro all Creation a Double Six-fold Wonder!

Away from ololon she divided \& fled into the depths of Miltons Shadow as a Dove upon the stormy Sea.

Then as a Moony Ark Ololon descended to Felphams Vale In clouds of blood, in streams of gore, with dreadful thunderings

Into the Fires of Inteliect that rejoic'd in Felphams Vale

Around the Starry Eight: with one accord the Starry Eight became

One Man Jesus the Saviour. wonderful! round his limbs The Clouds of Ololon folded as a Garment dipped in blood

Written within \& without in woven letters: \& the Writing

Is the Divine Revelation in the Litteral expression:

A Garment of War, I heard it namd the Woof of Six Thous and Years.

$(42: 2-15)$

This is precisely the vision recorded on plate 24 of The Marriage of Heaven and Hell seen now not from a mortal, twofold, infernal perspective, but from the Eternal, fourfold, Human perspective. The vision lasts for only a moment, and Blake returns to his mortal state, 
"To Resurrection \& Judgment in the Vegetable Body" (42:27). Yet now the gates to Golgonooza stand wide open in Blake. Strengthened by the double portion of the spirit of prophecy, he is ready, indeed compelled, "To go forth to the Great Harvest \& Vintage of the Nations." 
CHAPTER V

TILL WE HAVE BUILT JERUSALEM

"Again he speaks in thunder and in fire!

Thunder of Thought \& flames of fierce desire:

Even from the depths of Hell his voice I hear, Within the unfathomd caverns of my Ear.

Therefore I print; nor vain my types shall be. Heaven, Earth \& Hell, henceforth shall live in harmony."

$$
\text { ( } 3: 5-10)
$$

Jerusalem, Blake's last engraved poem, is also the largest completed work in his canon and surely his culminating masterpiece. In this epic, approximately twice as long as Milton--in four chapters, one hundred plates, and some 4000 lines compared to two books, fifty plates, and some 2000 lines, Blake fulfills, at last, the promise made In The Marriage of Heaven and Hell, when he announced his own Messiahship and the dawning of the new age. Obviously, the limited scope of this paper does not allow for an extended treatment of this or any other of the poet's major works, Even The Marriage of Heaven and Hell has been handled only in part, and, in my view, the completely satisfactory analysis of Jerusalem has not been done at any length by any critic. However, a very brief analysis should be sufficient to provide directional arrows for a future, more detailed study of the realization of Blake's Apocalypse. 
The numbers game various critics play to find a defineable structure for Jerusalem bears a good deal of fruit; yet I believe much of it is unnecessary for my purpose of understanding just what the poem is and how it works in relation to Blake's overall scheme. These matters become clear when we recall the principles outlined in The Marriage of Heaven and Hell and elaborated in Milton, for here again in Jerusalem those principles, as well as the epiphanic vision of the two earlier works, are given epic expansion. The links are many and various, but no where more obvious than on plate 83:

While Los arose upon his Watch, and down from Golgonooza

Putting on his golden sandals to walk from mountain to mountain,

He takes his way, girding himself with gold \& in his hand

Holding his iron mace:

$$
\text { (83:75-78; italics mine.) }
$$

This passage brings several things to mind at once. First, it reminds us of a parallel passage in Milton:

While Los heard indistinct in fear, what time I bound my sandals

On; to walk forward tho' Eternity, Los descended to me: And Los behind me stood; a terrible flaming Sun: just close

Behind my back; I turned round in terror, and behold.

Los stood in that fierce glowing fire; \& he also stoop'd down

And bound my sandals on in Udan-Adan. . ( $\dot{M}$ 22:4-9)

So we know that Los is joined with Blake and Milton and that the work of Jerusalem will be similar to that of Milton, which enabled the seventeenth-century English poet-prophet to purify himself of his Selfhood and gave 
the nineteenth-century one the clarity of vision to

fabricate the mythology in which the former could undertake his great struggle. In this last epic, however, the labor against the Selfhood is undertaken by Los himself:

And feeling the damps of death they with one accord delegated Los

Conjuring him by the Highest that he should watch over them

Till Jesus shall appear: \& they gave their power to Los

Naming him the Spirit of Prophecy, calling him Elijah. (J $39[44]: 28-31)$

Therefore, the goal of that labor must be nothing short of the Apocalypse promised in The Marriage of Heaven and Hell and prepared in Milton.

In the first section of this paper I outlined the following four principles as the essential subject of The Marriage of Heaven and Hell:

1. Man's nature is fourfold, and the fully realized potential of that nature is the identity of the divine.

2. Each man's individuality, expressed in his desires and energies, is intrinsically valuable, and therefore no one man's vision is sufficient to be imposed externaliy upor others.

3. Perception through the five senses is essentialiy subjective and greatly limited when closed to the non-sensory dimension of the imagination.

4. One must be willing to krow excess in order to approach a balance between his contrary aspects of "purposive activity and restorative passivity" (i.e., the Prolific and the Devouring). 
These principles, combined with the awareness that the Book of Revelation, modulated through Paradise Regained, again provides Blake with a model, serve to clear up the complexities of Jerusalem. The significance of the first of these is obvious; the entire course of Blake's art is meant to establish human awareness of that divine identity. The second principle is manifest in the crucial remarks of Los:

I must Create a System, or be enslav'd by another Mans

I will not Reason \& Compare: my business is to Create Striving with systems to deliver Individuals from those Systems. . .

$$
(10: 20-21 ; 11: 5)
$$

The working out of this second principle, through an understanding of the full implications of the third and the fourth, is the singular method by which the goal of the first principle is realized. An understanding of these last two is essential, for:

The Spectre is the Reasoning Power in Man; \& when separated

From Imagination, and closing itself as in steel, in a Ratio

of the Things of Memory. It thence frames Laws \& Moralities

To destroy Imagination! the Divine Body, by Martyrdoms \& Wars.

$(74: 10-13)$

Thus, in the struggle for redemption:

Where Luvahs World of Opakeness grew to a period: It Became a Iimit, a Rocky hardness without form \& void Accumulating without end: here Los who is of the Elohim

opens the Furnaces of affliction in the Emanation 
Fixing the Sexual into an ever-prolific Generation Naming the Limit of Opakeness Satan \& the Limit of Contraction

Adam, who is Peleg \& Joktan: \& Esau \& Jacob: \& Saul \& David

Voltaire insinuates that these Limits are the cruel work of God

Mocking the Remover of Limits \& the Resurrection of the Dead

Setting up Kings in wrath: in holiness of Natural Religion

Which Los with his mighty Hammer demolishes time on time

In miracies \& wonders in the Four-fold Desart of Albion Permanently Creating to be in Time Revealed : Demolished.

$(73: 22-34)$

Finally, there can be nothing which to the reasoning or Devouring mind seems more "excessive" than the annihilation of the Spectrous Selfhood:

In man's struggle with death, whoever breaks the barriers of materialism, egocentricity, or morality that man has set against death appears to betray him. That agent, whether in his naturalized form of sexuality or in his spiritual form of imaginative desire, is Luvah. I

The ultimate form of this "excess," and therefore the form most feared and suppressed, is the self-sacrifice of one friend for another. Nonetheless

Albion replyd. Cannot Man exist without Mysterious Offering of Self for Another, is this Friendship \& Brotherhood

I see thee in the likeness \& similitude of Los my Friend

${ }^{1}$ Stuart Curran, "The Structures of Jerusalem," in Blake's Sublime Allegory: Essays on the Four Zoas, Milton, Jerisalem, ed. Stuart Curran and Joseph Anthony Wittreich, Jr. Madison: The University of Wisconsin Press, 1973), p. 342 . 
Jesus said. Wouldest thou love one who never died For thee or ever die for one who had not died for thee And if God dieth not for Man \& giveth not himseif Eternally for Man Man could not exist! for Man is Love: As God is Love: every kindness to another is a little Death

In the Divine Image nor can Man exist but by Brotherhood.

$(96: 20-28)$

As Stuart Curran has noted, the model for Jerusalem (other than Revelation) is Paradise Regained, a fourfold epic relating a tripartite contention of Satanic and Messianic vision. But the three temptations are merely three progressively intensifying angles of perception of the same thing. Satan is clearly and completely defeated in his first encounter with the son. This fact comes even more sharply into focus in the subsequent books of the epic until, at last, on the pinnacle, both he and Christ, as well as the reader, recognize the full extent of his failure, as the Demon is literally hurled down and the son is exalted. Here then is the explanation for the threefold recounting of the deaths of Albion and Luvah and the threefold embracing of Albion and the Savior. The Fall and Last Judgment are eternally now:

whenever any Individual Fejects Error \& Embraces Truth, a Last Judgment passes upon that Individual.

(VLJ 551)

Thus, Blake constantly shifts tense from present to past and back again to present. In the same manner he repeats the same "events" over and over, often out of what the Urizenic thinker would call their "proper sequence." 
Indeed, the only action sultable for visionary poetry (the work of the Prolific) is that which is created by the poetry itself. That is, the action must have no external. existence beyond the boundaries of the poem itself. It cannot be the slave of another's system. ${ }^{2}$

Blake's System, of course, is not entirely without a source. On the contrary, he forges his new Sword for his Mental Fight to build Jerusalem (M 1:13-16) from the shards bequeathed him by his two great Christian prophetic forebearers, John of Patmos and Milton:

Pointedly, Milton concludes in the same moment from which Jerusalem unfolds, the end of the first poem and the beginning of the second having their primary referent in the first chapter of Revelation. Jerusalem begins, like Revelation.. . With Christ standing at the door knocking, with Blake taking in the vision of which his poem is an articulation. Jerusalem begins, that is, in the same moment with which Milton ends. Beholding Jesus in "Felphams Vale clothedin Clouds of blood" and hearing "Four Trumpets.. . sounded to the Four Winds," Blake is "Terror struck" and, trembling, falls "outstretchd upon the path" (M 42:20-25), just as John of Patmos, turning to see the voice that speaks to him and beholding the vision of Jesus, falls "to his feet as dead" (Rev. 1:17).3

The parallels of form continue throughout the epic. Each contains seven visions, and the substance of each of those visions receives similar treatment by the two prophets. John's Apocalypse begins with a vision of seven

\section{Ibid., p. 336 and elsewhere.}

3 Joseph Anthony wittreich, Jr., "Opening the Seals: Blake's Epics and the Milton Tradition," in Blake's Sublime Allegory: Essays on the Four Zoas, Milton, Jerusalem, (Madison: The University of Wisconsin Press, 1973), pp. $47-48$. 
messages to the seven churches; it then moves to a vision of God's judgment as revealed in the opening of the seven seals. "In John's third vision, of the seven angels with their trumpets, God allows the separation of the wicked and faithful: now 'the court which is without the temple - - is given unto the Gentiles: and the holy city shall they tread underfoot forty and two months" (11:2)." 4 Next, there is a vision of the appearance of the "Woman and the Dragon," the "beast coming up out of the earth," angels, and "the Lamb" who is the "Son of Man." 5 Then there is a vision of seven plagues brought by the harvesting angels. "God's judgment on Babylon and the appearance of Christ for battle comprise John's sixth vision," and his final vision depicts "the great battle and. . . Jerusalem descending. . . . $" 6$

The visions of Jerusalem follow this pattern exactly. (I) Blake questions "the nature of the fallen and visionary worlds," concluding on Plate 14 with a "survey of Golgonooza." (2) He reveals human judgment as "epitomized in Plate 28 with a description of the Tree of Moral Virtue," the Spectrous replacement for the Tree of Life and the cause of the suicidal and murderous psychosis rampant

${ }^{4}$ Curran, p. 338 .

5 Austin Farrer, A Rebirth of Images: The Making of St. John's Apocalypse (London: Dacre Press, 1949; rpt. Boston: Beacon Press, 1963), pp. 47-49.

${ }^{6}$ Curran, p. 338 . 
in the following plates. (3) The "confrontation between Albion and his Sons "recall[s] John's third vision." (4) Blake's fourth vision involves "the election of the Seven Eyes of God in Plate 55 and Los's attack on the Female Will (the Great Whore is carried by the Beast with seven heads and ten horns) in Plate 56." (5) The wine-presses of "warfare and sacrifice on earth" are depicted, and "in Plate 70 the Sons and Daughters of Albion aggregate in Hand and Rahab. . . ." (6) The "selfdestructive power play of the Daughters of Albion. . . provokes the voracious Hand to turn upon them." Unified as Rahab, they ask Los for help. "Here in Plate 84 Los is, like Christ, at last victorious." (7) Blake concludes with "Los's hymn to Jerusalem and.. . his leading the regenerate Albion to victory and union with his Emanation. The Antichrist's defeat occurs on Plate $98 . " 7$

one final point of similarity should be enough to demonstrate the extent of Blake's use of Revelation. Austin Farrer discusses the description of Jerusalem given at the end of Revelation:

[The] frame of the city (XXI), we observe [is such] that there are three gates to each side of the square, and that the twelve jewels are the blocks of continuous wall-foundation between the gaps made by the gates. The openings are closed each by a pearl. . . This expresses the dignity of the apostles as new

\footnotetext{
${ }^{7}$ Ibid., pp. $338-339$
} 
patriarchs, enthroned over the twelve tribes of Israel, one to each tribe. . . 8

Farrer provides several diagrams to illustrate various aspects of his discussion of the end of John's Apocalypse. I have duplicated what I believe to be the most appropriate one below and followed it with the map of Golgonooza realized by $S$. Foster Damon in his Dictionary. I believe I need say no more about the similarities at this time. Throughout this paper I have emphasized the deep relationship Blake felt with Milton, a relationship which, hardy either tyrranical influence or impetuous revolt, could only be called cooperation. Joseph Wittreich has provided me with the most valuable critical support on this issue, and so I turn again to him for my final remarks about this relationship:

To say that Blake is still searching for "vision" when he writes Jerusalem is mistaken, but what Bloom says of Blake's inverting the pattern of Ezekiel's vision is true enough. Indeed, such inversions are typical of the way prophets treat their predecessors, shifting their accents and presenting reverse images of earlier prophetic patterns. One need only recall that on virtually every cccasion when Milton derives a pattern from Homer or Virgil it is a pattern presented in reverse; the new pattern becomes a way of defining, through irony, the poet's unique discoveries.9

The same pattern is obvious in Blake with one important difference:

Milton would not take "dictation" from Homer, Virgil, and Dante. Neither did Blake. But in the same way

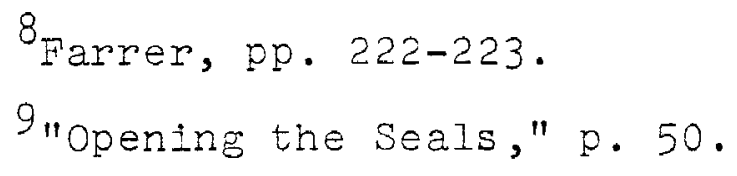

8Farrer, pp. 222-223.

9 "Opening the Seals," p. 50. 


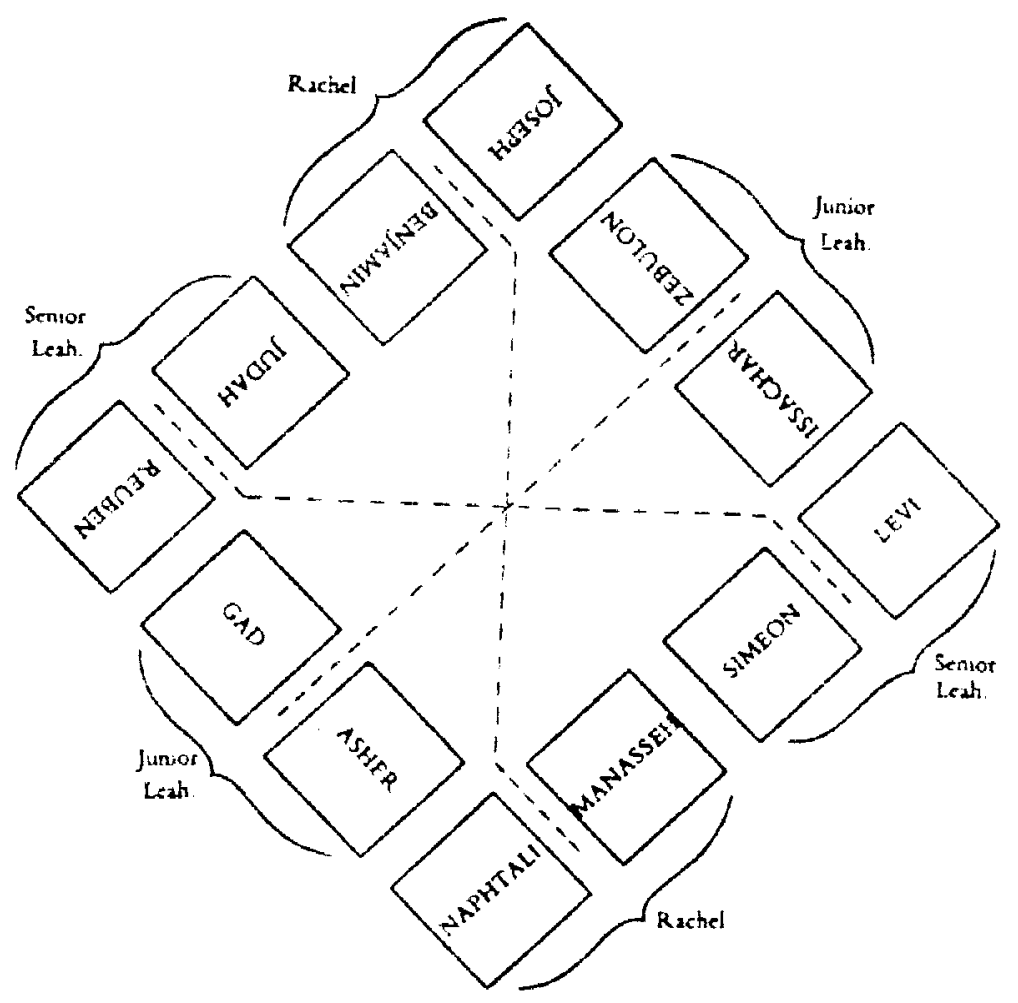

FIGURE 2: THE GRAME OF JERUSALEM

Farrer's diagram of the twelve enthroned tribes, described in Revelation 21, is provided on page 227 of his text. 


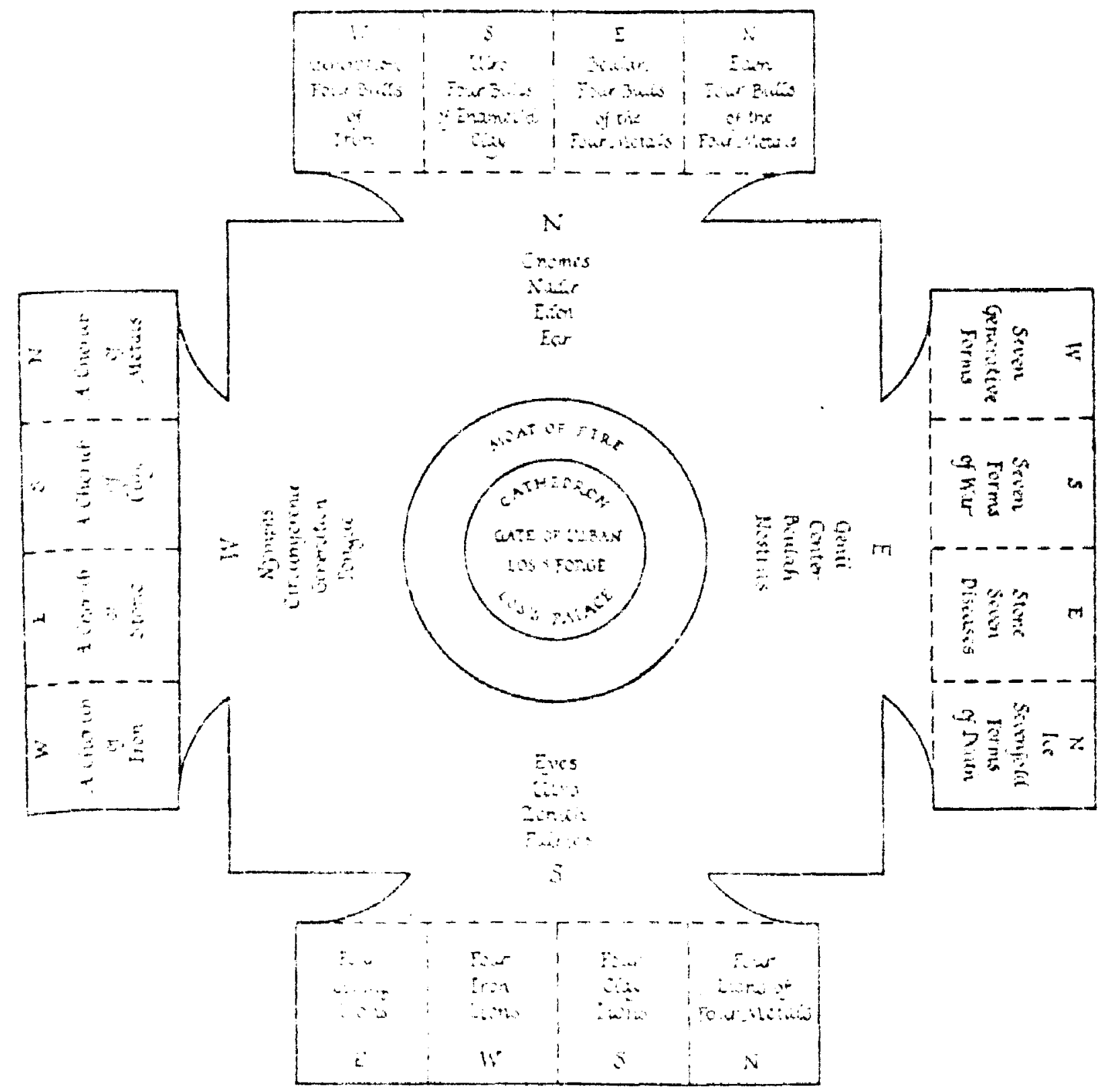

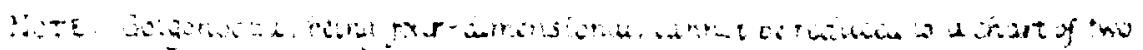

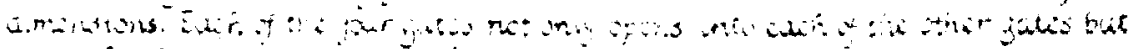

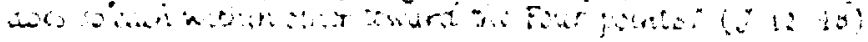

-

FIGURE 3: GOLGONOOZA

Provided by Damon on page 163 of his Dictionary. 
that Milton serves as God's secretary and takes dictation from all those biblical prophets who had previously recorded the word of God, Blake takes dictation from Milton--less from the poet who wrote Paradise Lost than from the poet who wrote Paradise Regained. Like Milton, Blake was not beyond shifting the accents and patterns of biblical prophecy: Blake does it in Jerusalem, and Milton does it most noticeably in Paradise Regained. Yet both poets have scriptural precedent for what they do. This is precisely what John does in the Apocalypse, and his practice both poets adhere to.10

Milton and Jerusalem, as well as The Marriage of Heaven and Hell, though taking their form and auite a few minute particulars from Revelation, derive their meaning from Paradise Regained. The two epics, as Wittreich has said, and the earlier prophecy also, "emphasize return - With the true poet-prophet-orator (Milton-Los-Blake), having annihilated selfhood, which is Satan, returning to civilization to begin the work of redemption." When Christ rejects Satan on the pinnacle, he demonstrates his divinity and the love for God which his divine origin implies. When, however, he returns "to his nother's house he displays his enormous love for man." That is, he establishes the identification of complete humanity with the divine. "This moment of return is Christ's deed above heroic, and it constitutes the moment when contemplation, having unfolded into vision, is translated into form and action."Il The Marriage and Milton have shown the visionary epiphany and have promised the action, but

$$
10 \text { Ibid. }
$$$$
{ }^{11} \text { Ibid., p. } 52
$$ 
Jerusalem actually is the action.

The precise architecture framed by that action is difficult to describe. Indeed, it is the premier difficulty facing critics of Jerusalem. Hazard Adams, in his very inteliigent essay, argues that the poem is "the establishment of linguistic or metaphorical identity in visionary time and space between holy Jerusalem and resurrected London. . . ; he shapes the Biblical vision into the English tongue."12 Los is "the builder of language," and his work is "the eternal recreation of the act that Blake attributes in The Marriage originally to the 'ancient Poets.' Since The Marriage is present to us, however, it is more appropriate to say that the act is not a recreation of but is identical to the act of the poets."13 This line of thinking is consistent with Roger R. Easson's contention that Albion, as an allegorical figure, stands for the reader of the poem, the poem for the reader's own Emanation (in its redeemed state a visionary fourfold drama, but obscured by a Corporeal narrative veil), and Los and the Savior for Blake himself. 14

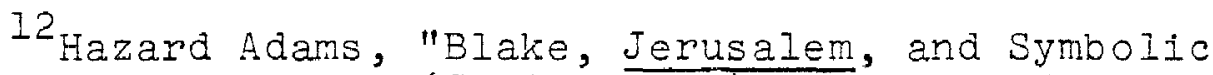
Form," Blake Studies, 7 (Spring 1975), p. 150. There are obvious echoes of Frye's important groundwork in Fearful Symmetry.

$$
13 \text { Ibid., p. } 151 \text {. }
$$

14 "William Blake and His Reader in Jerusalem," in Blake's Sublime Allegory: Essays on the Four Zoas, Milton, Jerusalem, ed. Stuart Currar and Joseph Anthony Wittreich, Jr. (Madison: The University of Wisconsin Press, 1973), pp. 309-327. 
Easson's essay, however, is too narrow in its view of so complex a work as Jerusalem.

The eternality of the poet's work is emphasized throughout writing, as Adams has argued. Karl Kroeber, in an ultimately unsatisfactory essay, does manage to establish firm support for this point in his linguistic analysis of the epic's concluding plate:

All Human Forms identified even Tree Metal Earth \& Stone. all

Human Forms identified, living going forth \& returning wearied

Into the Planetary lives of Years Months Days \& Hours reposing

And then Awaking into his Bosom in the Life of Immortality.

And I heard the Name of their Emarations they are named Jerusalem.

$(99: 1-5)$

In these lines, Kroeber tells us, "no word 'stands for' or 'represents' anything other than itself, just as in the poem as a whole Albion. . does not play the role of Everyman; Albion is man's uniting humanness. On every level Blake's style is anti-archetypal, anti-paradigmatic. He does not urge us to 'imitate' Christ, but, rather, to recognize--to see--that Christ is within each of us individually."15

The last line of the plate, the epic's closing sentence, structurally demonstrates the essence of Blake's

15"Delivering Jerusalem," in Blake's Sublime Allegory: Essays on the Four Zoas, Milton, Jerusalem, (Madison: The University of Wisconsin Press, 1973), p. 350 . 
philosophic and aesthetic principles. The sentence begins in the active voice, past tense, with a singular subject and the direct object Name. It ends with a plural subject, in the passive voice and present tense, having transformed the direct object into a verbal form, named. The entire structure ultimately collapses, both grammatically and semantically, into the final word of the epic, the name Jerusalem. Thus, in what from a fallen perspective is the terminal sentence of Blake's engraved prophetic canon, "at last, the condition of true, Regenerated reality is attained, a condition in which time, activity, and passivity, individuality and collectiveness, as we have known them in Generation, are transcended." 16

This transcendence of the classifications of Prolific and Devouring, of Particular and General is made possible by, indeed is the labor of Los, who, like the allegoric figures of the Printing House in Hell working "with molten metal to make books, . . uses ladles of ore, shaping potentiality into the spiritual sword." The ore with which this supreme poet-prophet works is none other than his own Selfhood. "Thus, Los is engaged in a struggle with his spectre--language converted to a sort of anti-myth." 17

$$
\begin{aligned}
& { }^{16} \text { Ibid., p. } 352 . \\
& 17_{\text {Adams, p. } 151 .}
\end{aligned}
$$


But the spectre, in all of its manifestations, is much more than perverted language. It is also the rationalistic fatalism in each individual, so easily aggregated into the oppressive law and morality of society. The Spectre is the embodiment of the "odds" against the poet, the visionary, humanity. Los compels these doubts, guilts, pessimistic feelings, and negative odds to do his will, smites them until they are transformed to perfect "the Space of Erin." That is to say, out of the struggle with his Spectre he creates the poem Jerusalem. On the threshold of Apocalypse Los cries out to his Spectre and reveals beyond doubt the unity of Blake's vision:

Go to these Fiends of Righteousness

Tell them to obey their Humanities, \& not pretend Holiness;

When they are murderers: as far as my Hammer \& Anvil permit

Go, tell them that the Worship of God, is honouring his gifts

In other men: \& loving the greatest men best, each according

To his Genius: which is the Holy Ghost in Man; there is no other

God, than that God who is the intellectual fountain of Humanity;

He who envies or calumniates: which is murder \& cruelty;

Murders the Holy-one. . .

$(91: 4-12)$

The language of Plate 24 of The Marriage of Heaven and Hell returns us to the epiphanic moment which, I have argued, is central (more properly in Blakean terms, the Circumference) to the canon. Here, at last, it is transformed so that "All the Lords people" and not just 
the poet may see the consummation and receive the mantle of prophecy. Jerusalem will, indeed, be "built... In Englands green \& pleasant Land" in the mind of anyone who reads and understands, for "Truth can never be told so as to be understood, and not be believ'd." Then the reader, forgiving what he does not approve, will become one Man with the Imagination of $B$ lake and will recognize the Minute Particulars of that Imagination as One Blake. 
SELECTED BIBLIOGRAPHY 
Adams, Hazard. "Blake, Jerusalem, and Symbolic Form." Blake Studies, 7 (Spring 1975), 143-166.

Altizer, Thomas J.J. The New Apocalypse: The Radical Christian Vision of William Blake. [East Lansing]: Michigan State University Press, 1967.

Beer, John. Blake's Visionary Universe. New York: Barnes \& Noble, Inc., 1969.

Blake, William. The Illuminated Blake. Ed. David V. Erdman. Garden City, N. Y.: Anchor Press/Doubleday, 1974 .

The Poetry and Prose of William Blake. Ed. David V. Erdman, rev. ed. Garden City, New York: Doubleday \& Company, Inc., 1970.

Bloom, Harold. Blake's Apocalypse: A Study in Poetic Argument. Garden City, N. Y.: Doubleday \& Company, Inc., 1963 .

Curran; Stuart. "The Structures of Jerusalem," in Blake's Sublime Allegory: Essays on the Four Zoas, Milton, Jerusalem. Ed. Stuart Curran and Joseph Anthony Wittreich, Jr. Madison: The University of Wisconsin Press, 1973, pp. 329-346.

Damon, S. Foster. A Blake Dictionary: The Ideas and Symbols of William Blake. Providence: Brown University Press, 1965.

William Blake: His Philosophy and Symbols. New York: Peter Smith, 1924.

Easson, Roger R. "William Blake and His Reader in Jerusalem," in Blake's Sublime Allegory: Essays on the Four Zoas, Milton, Jerusalem. Ed. Stuart Curran and Joseph Anthony Wittreich, Jr. Madison: The University of Wisconsin Press, 1973, po. 309-327. 
Eaves, Morris. "A Reading of Blake's Marriage of Heaven and Hell, Plates 17-20: On and Under the Estate of the West. Blake Studies, 4 (Spring 1972), pp. 81-116.

Erdman, David V. Blake: Prophet Against Empire: A Poet's Interpretation of HIs Own Times. Rev. ed. Princeton: Princeton University Press, 1969.

, and Grant, John E., ed. Blake's Visionary Forms Dramatic. Princeton: Princeton University Press, 1970 .

Farrer, Austin. A Rebirth of Images: The Making of St. John's Apocalypse. London: Dacre Press, 1949; rpt. Boston: Beacon Press, 1963.

Fisch, Harold. "Blake's Miltonic Moment." William Blake: Essays for S. Foster Damon. Ed. Alvin H. Rosenfeld. Providence: Brown University Press, 1969, pp. 36-56.

Fisher, Peter F. The Valley of Vision: Blake as Prophet and Revolutionary. Ed. Northrop Frye. Toronto: University of Toronto Press, 1961.

Frosch, Thomas R. The Awakening of Albion: The Renovation of the Body in the Poetry of William Blake. Ithaca: Cornell University Press, 1974.

Frye, Northrop. "Blake's Reading of the Book of Job," in William Blake: Essays for S. Foster Damon. Ed. Alvin H, Rosenfeld. Providence: Brown University Press, 1969, pp. 221-234. - Fearful Symmetry: A Study of William Blake. Princeton: Princeton University Press, 1947.

Geoffrey of Monmouth. History of the Kings of Britain. Trans. Sebastian Evans. Revised by Charles W. Dunn. New York: E. P. Dutton \& Co., Inc., 1958.

Grant, John E., ed. Discussions of William Blake. Boston: D. C. Heath and Company, 1961 .

Grimes, Ronald L. "Time and Space in Blake's Major Prophecies," in Blake's Sublime Allegory: Essays on the Four Zoas, Milton, Jerusalem. Ed. Stuart Curran and Joseph Anthony Wittreich, Jr. Madison: The University of Wisconsin Press, 1973, pp. 59-81. 
Hamblen, Emily S. On the Minor Prophecies of William Blake. New York: Haskell House Publishers, Ltd., 1930 .

Jackson, Mary V. "Prolific and Devourer: From Nonmythic to Mythic Statement in The Marriage of Heaven and Hell and A song of Liberty. Journal of English and Germanic Philology, 70 (1971), pp. 207-219.

Kroeber, Karl. "Delivering Jerusalem," in Blake's Sublime Allegory: Essays on the Four Zoas, Milton, Jerusalem. Ed. Stuart Curran and Joseph Anthony Wittreich, Jr. Madison: The University of Wisconsin Press, 1973, pp. 347-367.

Lewalski, Barbara Kiefer. Milton's Brief Epic: The Genre, Meaning, and Art of Paradise Regained. Providence, R. I.: Brown University Press, and London: Methuen \& Co., Ltd., 1966.

Locke, John. An Essay Concerning Human Understanding. Ed. Maurice Cranston. London: Collier-MacMillan, Ltd., 1965.

Marcuse, Herbert. Eros and Civilization: A Philosophical Inquiry into Freud. Rev. ed. New York: Vintage Books, 1962 .

Milton, John. Complete Prose Works of John Milton. 6 vols. New Haven: Yale University Press, and London: Oxford University Press, 1953-73.

- The Complete Poetry of John Milton. Ed. John T. Shawcross. Rev. ed. Garden City, N. Y.: Doubleday \& Company, Inc., 1971.

Nurmi, Martin K. "On The Marriage of Heaven and Hell," In Discussions of William Blake. Ed. John E. Grant. Boston: D. C. Heath and Company, 1961, pp. 93-101.

Percival, Milton 0 . William Blake's Circle of Destiny. New York: Octagon Books, Inc., 1964.

Plowman, Max. An Introduction to the Study of Blake. London: Gollancz, 1952 .

Rieger, James. "The Hem of Their Gamments': The Bard's Sorg in Milton," in Blake's Sublime Allegory: Essays on the Four Zoas, Milton, Jerusalem. Ed. Stuart Curran and Joseph Anthony Wittreich, Jr. Madison: The University of Wisconsin Press, 1973, pp. 259-280. 
Rose, Edward J. "Blake's Milton: The Poet as Poem." Blake Studies, 1 (Fall 1968), pp. 16-35.

Singer, June $K$. The Unholy Bible: A Psychological Interpretation of William Blake. New York: G. P. Putnam's Sons for the C.G. Jung Foundation for Analytical Psychology, 1970 .

Tatlock, J. S. P. The Legendary History of Britain: Geoffrey Monmouth's Historia Regum Britanniae and Its Early Vernacular Versions. Berkley: University of California Press, 1950.

Taylor, Irene. "Say First! What Mov'd Blake? Blake's Comus Designs and Milton," in Blake's Sublime Allegory: Essays on the Four Zoas, Milton, Jerusalem. Ed. Stuart Curran and Joseph Anthony Wittreich, Jr. Madison: The University of Wisconsin Press, 1973, pp. 233-258.

Taylor, Peter Allen. Blake's Milton." pp. $43-60$.

"Providence and the Moment in Blake Studies, 4 (Fall 1971),

Vogler, Thomas A. Preludes to Vision: The Epic Venture in Blake, Wordsworth, Keats, and Hart Crane. Berkley: University of California Press, 1971.

Wittreich, Joseph Anthony, ir. Angel of Apocalypse: Blake's Idea of Milton. Madison: The University of Wisconsin Press, 1975.

"Blake's Philosophy ồ Contraries: A New Source." English Language Notes, 4 (December 1966), pp. 105-110.

- "Opening the Seals: Blake's Epics and the Milton Tradition," in Blake's Sublime Allegory: Essays on the Four Zoas, Wilton, Jerusalem. Ed. Stuart Curran and Joseph Anthony wittreich, Jr. Madison: The University of Wisconsin Press, 1973, pp. 23-58.

ed. The Romantics on Milton: Formal Essays and Critical Asides. Cleveland: The Fress of Case Western Reserve University, 1970. 
VITA

The author, Richard Lee Record, is the son of Marco E. Record and Edna Mae (Crosby) Record. He was born August 28, 1952, in Louisville, Kentucky.

His elementary education was obtained in the public schools of Louisville, Kentucky, and secondary education at Iroquois High School, Louisville, Kentucky, where he was graduated in 1970 .

In August, 1970, he entered the University of Louisville, and in May, 1974, received the degree of Bachelor of Arts with a major in English. In 1973 he was awarded the Thomas Scholarship. He was elected a member of Delta Phi Alpha German Honorary and of the Woodcock Society in 1974

In August, 1974, he was granted an assistantship in English at the University of Louisvilie. In December, 1976, he was awarded the Master of Arts in English. 